УдК 930.2

\title{
А.В. Овчинников
}

\section{АРИЙСКИЙ МИФ В НАЦИОНАЛИЗМАХ СОВРЕМЕННОГО ТАТАРСТАНА}

\author{
Публикаџия подготовлена при поддержке гранта РГНФ № 15-33-01003 «Конщептуальные основания политики памяти
} и перспективы постнациональной идентичности».

\begin{abstract}
Анализируются особенности функционирования арийского мифа в национализмах Татарстана - республики в составе Российской Федерации. Констатирована распространенность этого мифа на постсоветском пространстве. Указано на недостаточную, по мнению автора, изученность темы на материалах Татарстана. В процессе решения данной научной проблемы выявлены апелляции к «арийству» представителями булгарского, татарского, кряшенского и русского национализмов. Делается вывод об инструментальном использовании арийского мифа в современных татарстанских национализмах.

Ключевые слова: арийский миф; булгары; татары; кряшены; национализм; Гиперборея; неоязычество.
\end{abstract}

Одной из распространенных мифологем XIX$\mathrm{XX}$ вв. являлся так назваемый арийский миф, суть которого сводилась к отождествлению некой современной группы населения с древними и благородными «арийцами», пришельцами с далекого севера, из Гипербореи, Атлантиды или Арктиды (Арктогеи), которым мир обязан важнейшими изобретениями и достижениями культуры. Различные вариации этого мифа постулировали, что их потомки, в противоположность былому величию, оказались вынужденными жить в окружении многочисленных и коварных врагов, которые, нередко выступая в образе капиталистов-ростовщиков, нарушали законы моральной экономики и с которыми якобы имелись ещё и «исторические счеты». Печальные последствия пропаганды арийского мифа в нацистской Германии хорошо известны.

Казалось бы, в странах постсоветского пространства, в своё время высокой ценой победивших фашизм, более или менее массовые спекуляции на «арийскую тему» никогда не возникнут, и эта риторика останется уделом маргинальных ультраправых группировок. Однако после распада Советского Союза на его бывших территориях наблюдался и наблюдается феномен архаизации и демодернизации социально-политических отношений, который выражается, в том числе, и в мифизации как массового сознания, так и формально академических практик объяснения настоящего и прошлого (см., например, сюжеты так называемых национальных историй).

О серьезности проблемы, а следовательно, и актуальности её изучения говорит хотя бы тот факт, что, например, в Таджикистане «арийство» стало частью государственной идеологии [1. С. 215-222]. В этой стране арийский миф, похоже, начинает выполнять функцию квазиобъяснения социального и политического неравенства. Так, по сообщениям электронных СМИ, жительницу одного из райцентров этой республики не допустили на встречу с Президентом Э. Рахмоном на основании не соответствия ранее установленным требованиям: «высокий рост, грамотная речь и арийская внешность» [2].

Распространение арийского мифа в современной России так или иначе изучалось целым рядом авторов, среди публикаций которых следует отметить фундаментальную двухтомную монографию В.А. Шнирельмана «Арийский миф в современном мире» [3] и диссертацию на соискание ученой степени кандидата исторических наук К.А. Жарчинской «Славяноарийский миф в историческом сознании российских традиционалистов» [4].

К уже введенному исследователями в научный оборот корпусу источников, на мой взгляд, следует добавить несколько новейших примеров, маркирующих проблему явного присутствия «мифического» компонента в отечественных учебных изданиях. В академическом учебнике «История России...» один из параграфов красноречиво назван «Индоевропейцы и первый “раздел Европы”» [5. С. 17]. Членкорреспондент РАН, известный историк А.Н. Сахаров эмоционально рассказывает о «триумфальном распространении индоевропейцев по Евразии» [Там же. С. 19]. Причем их расселение носило далеко не мирный характер, например, «клин индоевропейских поселений врезался в среду обитания угро-финских народов» [Там же. С. 20] и «наши древние предки», «воинственные, энергичные индоевропейщы... бились за удобные земли, щедрые рыбные угодья, богатые зверьём леса» [Там же. С. 21]. Воспевание и оправдание воинственной индоевропейской (фактически арийской, хотя это слово в учебнике не употребляется) героики не оставляют шансов для «побежденных» (т.е. предков финно-угров) и, при прочих условиях, по-моему мнению, может подготовить читателя к восприятию менее завуалированных вариантов арийского мифа.

В посвященном истории отечественной культуры учебном пособии А.И. Юрьева [6] рассказывается о том, что праславяне вместе с ариями задолго до нашей эры жили на территории современного Русского Севера. После похолодания праславяне и арии переселились на юг в Волго-Уралье, затем арии мигрировали еще дальше на юг, а праславяне остались в Европе. Расселение восточных славян в VI-VII вв. н.э. преподносится А.И. Юрьевым как возвращение «в те места, которые были освоены их далекими предками праславянами еще в древнейшие времена» [Там же. C. 4], причем об автохтонности балтов и финно-угров не говорится, лишь констатируется, что «славяне $c$ ними ассимилировались или соседствовали» [Там же].

Арийский миф в контексте русского национализма откровенно, с перечислением имен известных расистов и мало скрываемой симпатией к неоязычеству, пропагандируется в вышедшем в Казани вузовском 
учебнике «История» [7. С. 29-31, 40, 42-45]. В силу того что этот случай имеет прямое отношение к Татарстану, взгляды одного из авторов учебника, доктора исторических наук, профессора и вместе с тем апологета Гипербореи и арийского мифа И.А. Гатауллиной будут специально рассмотрены в данной статье.

Приведенные примеры иллюстрируют факт проникновения арийского мифа в академические и вузовские учебные издания, что не может не вызывать тревоги и лишний раз подтверждает важность научного анализа этого явления.

Историография изучения арийского мифа, включая разработку периодизации, исчерпывающе представлена в названной диссертационной работе К.А. Жарчинской [4. С. 4-7], что позволяет подробно не останавливаться на обзоре литературы. Замечу лишь, что некоторые касающиеся арийского мифа материалы Татарстана (нарративы булгарских националистов и внимание русских неоязычников к творчеству художника К. Васильева (1942-1976)) в контексте других регионов России и стран ближнего и дальнего зарубежья рассматривались В.А. Шнирельманом [3. T. 1. С. 278; Т. 2. С. 72, 224, 246].

На сегодняшний день в научной литературе отсутствует комплексное исследование, посвященное анализу особенностей использования арийского мифа в булгарском, татарском, кряшенском и русском национализмах современного Татарстана. Предлагаемая вниманию статья представляет собой попытку приблизиться к решению выявленной научной проблемы.

На первый взгляд, «арийству» в Татарстане сложно завоевать сколь-либо прочные позиции. В выходящих в Казани исторических сочинениях носители восточноевропейских, среднеазиатских и алтайских археологических культур эпохи бронзы и раннего железного века (в том числе скифы, сарматы и савроматы), признанные наукой ираноязычными, часто атрибутируются как тюрки. Кроме того, авторы, «доказывающие», например, тюркоязычность спартанцев, нередко подчеркивают связь индоевропейской теории с фашизмом и даже коммунизмом (так, Ф.Ш. Фаттахов в своей монографии, посвященной прототюркам, обвинял советскую власть в уничтожении языков неиндоевропейских народов; в этом с ним соглашался доктор филологических наук М.Б. Хайруллин) [8. С. 329-332; 9. С. 7]. С политических позиций критикует индоевропоцентризм М.З. Закиев - доктор филологических наук, академик Академии наук РТ, в 1996-2000 г. - директор Института языка, литературы и искусства АН РТ. По его мнению, признание народов, появившихся во II тыс. до н.э. на территориях от Малой Азии, Мессопотамии, Ирана и Индии до границ Китая, индоиранскими, в конечном счете связано с европоцентризмом и колониализмом [10. С. 19].

Критика индоевропоцентризма соседствует со стремлением использовать искусственно «тюркизированные» сюжеты древней истории индоиранцев в своих целях. Ниже я постараюсь показать, что два основных лагеря современных татарстанских историков (так называемые булгаристы и татаристы) активно используют элементы арийского мифа для конструирования актуальных этногенетических повествований.
«Булгаристы» связывают происхождение современных казанских татар с волжскими булгарами основным населением Волжской Булгарии (небольшого государственного образования, существовавшего в Среднем Поволжье в X-XIII вв.) (подробнее см.: [11]). Наиболее радикальные представители булгаристского лагеря заявляют о «дискриминации» булгар и призывают вернуть татарам их «настоящее имя»«булгары» (см., например: [12-14]).

С политической точки зрения, одним из изъянов булгарской теории происхождения казанских татар является её автохтонизм, когда соблазнительные для этнонационалистического дискурса известные государства древности и Средневековья оказываются вне его рамок (ассоциируемый с татарами образ Золотой Орды «занят» «татаристами» и поэтому не может активно использоваться). Эту проблему в какой-то мере, видимо, призвана решить апелляция к «арийству».

В публикациях упоминавшегося «булгариста» М.3. Закиева индоиранская история превращается в историю тюркскую. В работе 2003 г. он доказывал, что «этноним ар/эр - тюркское слово со значением “люди, мужчины”"», который «вошел в состав этнонимов и сумеров (т.е. шумер. - А.О.), и хорасмиев, булгар, суар, хазар, савир, татар, авар, мишар, салар, yйгур» [10. С. 370]. Эта сомнительная логика позволила М.З. Закиеву парфян, согдийцев, тохаров, кушанов и собственно ариев «превратить» в тюрков, которые якобы «имели самые тесные контакты с предками булгар, расположенных в Западной Сибири, УралоПоволжье, на Северном Кавказе» [Там же. С. 372373]. Со временем «арийство», видимо, еще больше заинтересовало М.3. Закиева, и в его книге 2008 г. появляется целый раздел с говорящим названием «Арийские и хуннские этнические корни тюрков» [15. С. 173-199]. В ней постулируется, что тюркские арийские племена ещё в глубокой древности жили вперемежку с другими тюрками в Малой, Передней, Средней и Центральной Азии, в Восточной Европе, на Кавказе и Балканском полуострове. Методологической базой таких смелых утверждений являлась игра словами, содержащими созвучие «ар» [Там же. С. 174]: «все тюркоязычные племена, обозначенные этнонимом “ар/ир”, являются арийскими этническими корнями тюрков» [Там же. С. 190].

В первую очередь, арийскими тюрками «оказались» шумеры [Там же. С. 179]. Тюркский язык в шумерской клинописи якобы закрепился 8000-8500 тыс. лет назад [Там же. С. 182]. Согласно М.3. Закиеву, и зороастризм был создан тюркоязычными племенами, а Авеста, возможно, записана на одном из тюркских языков [Там же. С. 177]. В свою очередь, «этноним тюрк» причислен к «арийской группе» («доказательству» этого М.3. Закиев посвятил целый параграф своей книги) [Там же. С. 185-188]. Как нетрудно догадаться, этноним «татары» также якобы арийского происхождения [Там же. С. 189, 190].

Влияние арийского мифа сказывается и на «историко-лингвистических исследованиях» (как он их сам называет) писателя Н. Фаттаха. Очевидной калькой «гиперборейского сюжета» является его утверждение о том, что, по представлениям египтян (в его понима- 
нии - предков булгар), на северном полюсе «сущзествовала вечная жизнь, - откуда дул благотворный, спасительный ветер» [16. С. 320]. Через 9 лет после цитируемой работы этот же автор утверждал, что «египетские пирамиды были построены как претворение в жизнь идеи северной горы и мудрых предков, обитающих на снежных вериинах» [17. С. 32]. Кроме того, слогу -ар он придавал значение положительного прилагательного, которое в древних языках, по его мнению, значило «священный, обожествленнылй, достойный великого почитания, чистый, благородныйџ и т.д., что не может не навести на параллели с «благородными арийцами». Интересно заметить, что область расселения тюрок в эпоху Средневековья от Урала до Алтая он именовал «Арка» (по его мнению, это соответствовало значению «иль, государство, родина») [16. С. 51].

Сторонник булгарской версии происхождения казанских татар, учитель истории Ф.Г.-Х. Нурутдинов, ссылаясь на поддельный свод булгарских летописей «Джагфар тарихи» и отрывки (в дальнейшем якобы «утраченные») из мифической книги «Хон китабы», в 1990-х гг. сконструировал наиболее эпичный вариант булгаро-арийского мифа. Среди специалистов нет единого мнения об источниках, на базе которых были созданы упомянутые подделки. Ю. Шамилоглу находит параллели между «Джагфар тарихи» и некоторыми опубликованными источниками XVIII-XIX вв. и более раннего времени [18. С. 37].

Изучение содержащихся в публикациях Ф.Г-Х. Нурутдинова исторических построений позволяет выдвинуть гипотезу, что одним из источников его «вдохновения» был славяно-русский вариант арийского мифа. Можно предположить, что из опубликованных до начала 1990-х гг. сочинений русских националистов (В.И. Скурлатова, В.И. Щербакова (19382004) и др.) черпались идеи, под которые затем «подгонялся» текст «Джагфар тарихи» (выполнявшей роль «Велесовой книги») и других фальшивок. Скорее всего, были позаимствованы такие структурные элементы мифа, как «прародина», «масштабные миграции», «участие в становлении известных цивилизаций древности», «культуртрегерство», «эквилибристика созвучиями этнических и географических названий», «вставки в историческое повествование мифических сюжетов».

Для подтверждения выдвинутой гипотезы, обратимся к одной из первых пространных статей Ф.Г-Х. Нуругдинова «Булгары и мировая цивилизация», которая появилась в 1993 г. В начале повествования автор с нескрываемой обидой на «историков-фантастов» (т.е. профессиональных исследователей) писал о сложившихся представлениях о булгарах «как народедомоседе, тихо и неприметно живщем в глухом лесном районе при слиянии могучих рек - Волги и Камы... В действительности, государство булгар тысячелетиями охватывало огромную территорию от Дуная до Енисея...» [19. С. 324]. Эта мифологема перекликается с появившимися в печати 14 годами ранее постулатами В.И. Скурлатова: «...не Припятские болота, куда нас пытаются загнать некоторые археологи, а огромный простор Евразийских степей вплоть до
Амура - вот наша истинная (русская. - А.О.) прародина» [20. C. 57].

Ф.Г.-Х. Нурутдинов утверждал, что 35 тыс. лет назад в суровых условиях Ледникового периода огузотюркские и североиранские («сакланские») предки булгар заселяли пещеры Уральских гор, а Волго-Уралье они именовали Ара (Арья) или Ура (от чего якобы произошли слова Туран, Урал, Арья и Иран). И иранские, и тюркские племена он называл «арийцами» [19. С. 324]. В представлении В.И. Щербакова предки славянарийцев (так называемые восточные кроманьонцы, они же восточные атланты) первоначально жили в пещерах Восточного Средиземноморья и оставили после себя производящие «неизгладимое впечатление» росписи пещер [21. С. 164, 167], так же как предки булгар, по Ф.Г.-Х. Нурутдинову, «написали 35 тысяч лет назад первые человеческие картиныл» на стенах знаменитой Каповой пещеры на Урале [19. С. 331].

В построениях Ф.Г.-Х. Нурутдинова прослеживается влияние гиперборейского мифа, в некоторых своих вариантах помещавшего прародину славянарийцев на далеком Севере. Так, арийцы, проживая в Волго-Уралье, кроме всего прочего якобы охотились на китов, тюленей и моржей [Там же. С. 325], что возможно только при условии «их выхода» к берегам Северного Ледовитого океана.

Согласно фантазиям Ф.Г.-Х. Нурутдинова, предки булгар 15 тыс. лет назад образовали союз семи арийских племен и затем создали первое в мире государство Идель [Там же. С. 327], характеристики которого напоминают основные черты Гипербореи или Атлантиды - в построениях русских националистов - высокоразвитой прародины арийцев.

Параллельно с «государственным строительством» и охотой на мамонтов [Там же. С. 325] «арийцыидельцы» стали первыми металлургами, «лучшими в мире обработчиками мехов и изготовителями всевозможных кож и обуви», изобретателями складного стула, кирпича, денег, стремени, сабли, пушки, ружья (судя по контексту этой части рассматриваемой статьи, речь идет о Ледниковом периоде...) [Там же. С. 331]. Видимо, мы имеем дело, в том числе, и с «развитием» используемого русскими националистами сюжета об известном холме Чатал-Гуюк в Малой Азии. В.И. Щербаков за 6 лет до Ф.Г.-Х. Нурутдинова писал о том, что материалы оставленного якобы «предками руссов» археологического памятника «на две тысячи лет увеличили возраст первоначального искусства металлургии», а также о таких изобретениях «восточных кроманьонцев» (они же, напомню, «восточные атланты»), как «одежда из кожи и замши, способ дубления и обработки икур» [21. С. 166-167].

Еще в 1977 г. В.И. Скурлатов отвергал мешавшее глобальным миграционным фантазиям мнение о славянах как исконных земледельцах, считая, что «русы» изначально были пастухами, бродившими со своими стадами по огромной территории евразийских степей [22. C. 331]. Те же коннотации можно обнаружить у Ф.Г.-Х. Нурутдинова, который объявлял предков булгар «отменными скотоводами и ремесленниками», лишь в случае разорения вынужденно переходившими к земледелию и «жизни в селениях и городах», «но 
ицет идельцев оставался верен полукочевому животноводству» [19. С. 327].

12 тыс. лет назад «арийцы» оказались вынужденными покинуть Волго-Уралье и мигрировать по просторам Евразии и Америки. Причиной тому стал приход с востока финно-угров. Этот сюжет позволял Ф.Г.-Х. Нурутдинову представить современных казанских татар (по его версии, «булгар») автохтонами региона. «Тяжелые времена» для государства булгарарийцев напоминают случившуюся, по мнению В.И. Щербакова, 11800 лет назад (т.е. почти «тогда же») катастрофу, когда Атлантида ушла на дно океана, а атланты были разгромлены восточными кроманьонцами [21. С. 162, 164].

И «булгарский», и «русский» варианты мифа подчеркивают культуртрегерскую роль ариев. Согласно Ф.Г-Х. Нурутдинову, «свои обычаи, мифы и достижения булгары разнесли по всему миру, так как широко, с истинно эпическим масштабом, расселились по земле» [19. С. 332]. По В.И. Скурлатову, воиныконники арийцы-русы разносили «этнокультурные хромосомы» по всему миру - от Индии до Британских островов [23. С. 215].

Пути миграций арийцев-булгар и арийцев-русов схожи. Часть булгар, как считает Ф.Г-Х. Нурутдинов, из Волго-Уралья «ушла» на восток - в Центральную Азию и Америку. На Алтае булгары якобы задолго до начала Раннего железного века начали выплавлять железо, в Северном Китае построили много новых городов, пещерных храмов, мавзолеев и ступенчатых пирамид - пагод, распространяли булгарские мифы, установили обычай носить косы (в Манчжурии), дали имя р. Хуанхэ. Согласно Ф.Г.-Х. Нурутдинову, в Монголии пришельцы распространили миф о спасенном волком булгарском принце Чингизе, что подводило читателя к мысли о булгарском происхождении Чингисхана [19. С. 333]. Древняя китайская и в целом дальневосточная культура волновала воображение и русских националистов. В 1982 г. вышел роман В.А. Чивилихина «Память», в котором автор древнейшее население долины р. Хуанхэ объявлял индоевропейцами, которые якобы участвовали в этногенезе многих восточноазиатских народов, и «один из них оставил след даже в генеалогии Чингисхана» [23. С. 58]. По В.И. Скурлатову, в начале бронзового века следы «курганной культуры», оставленной, как нетрудно догадаться, предками русов, обнаруживаются «от Хуанхэ на востоке до Дуная на западе, от Палестины на юге до Прибалтики на севере» [24. С. 213].

Если одна часть арийцев-булгар, как утверждал Ф.Г.-Х. Нурутдинов, из Волго-Уралья «двинулась» на восток, то другая, по его мнению, - на юг. Последние якобы стали предками сако-массагетских племен и кушан, а также тех арийцев, которые завоевали полуостров Индостан и «сделали популярным булгарский символ земной радости и счастья - “свастику”» [19. C. 333]. Другие булгары, также выходцы из ВолгоУралья, по Ф.Г.-Х. Нурутдинову, создали в Междуречье государство Шумер, первой столицей которого был объявлен город «Ат-Алан», «по имени которого всю булгарскую ближневосточную державу некоторые источники называли Атлантидой» [19. С. 334].
В.И. Скурлатов утверждал, что предки русов расселялись из Причерноморья до Эгейского и Балтийского морей, на юге - до Закавказья, Малой Азии, Ближнего Востока, через Кавказ оказались в Иране, а «по Дону, Волге, Каспию и Узбою они искали пути в глубинь Средней и Центральной Азии» и с территории Средней Азии проникли на территорию Индостана [24. С. 213-214]. В начале 1990-х гг. «восточных атлантов» В.И. Щербаков «расселял» по Ливии, Двуречью, Египту, Северной Индии, Китаю и Японии, а «родственных» им венетов - по Малой Азии и далее на восток [25. С. 204; 26. С. 229-236]. Таким образом, использованный Ф.Г.-Х. Нурутдиновым образ Атлантиды, скорее всего, также был навеян штудиями русских националистов.

Булгарская «Атлантида» погибла в 3182 г. до н.э. во время потопа, который «подорвал могущество булгар Древнего Шумера» [19. С. 335]. Однако «ещё до потопа» булгары успели дать свои названия таким политическим и географическим районам, как Финикия, Крит, Анатолия, Армения, Албания, Эльбрус, Кавказ, Египет и т.д. «Построили» они и такие города, как Микены, Афины, Троя, Иерихон, Иерусалим, Урук, Ур, Киш, Вавилон [Там же. С. 334]. После потопа, согласно Ф.Г.-Х. Нурутдинову, для булгар начались трудные времена, их стали теснить враги - с севера киммерийцы, «или хетты», с юга афразийцы - среди которых, судя по дальнейшему изложению, были и предки евреев. Однако «враги» (среди которых «обнаруживаются» даже дорийцы, захватившие мужественно обороняемую булгарами 10 лет Трою...) попадают под влияние «высокой культуры» булгар. Именно булгарам греки «обязаны» демократией, Олимпийскими играми и т.д. После разгрома Трои булгары оказались в Италии, где, как уже можно догадаться, стали называться этрусками. Там они «основали» Рим, Венецию, Геную, Равенну и т.д. [Там же. С. 337, 338]. В этих построениях также без труда угадывается влияние славяно-арийского мифа: согласно В.И. Щербакову, «этрус$к и$-это, образно говоря, лист, оторванный от хеттославянского дерева» [21. С. 170].

В пользу гипотезы о том, что Ф.Г.-Х. Нурутдинов «переработал» известные ему на то время основные положения славяно-арийского мифа, говорит и факт наличия в его построениях скрытых антисемитских ноток, которые, копируя и «творчески развивая» построения своих коллег по мифотворчеству, наш автор, видимо, просто не заметил. Так, пришедшие из Волго-Уралья булгары-арийцы дали имя Палестине (якобы от булгарского Бал-и Стан «Область Булгар»), Иерусалиму (Ерсу Булем «Город Бога»), Иерихону (Джир Каган «Дух песни») [19. С. 334]. Булгарским оказывается и миф о спасении Моисея («булгарский котел у афразийцев (т.е. евреев. - А.О.) превратился в корзинку, а имя Магис-в “Моисей”») [Там же. С. 335]. Даже имя Бога Яхве евреи якобы позаимствовали у булгар [Там же. С. 338]. Афразийцы стали одной из причин гибели «булгарского государства» на Ближнем Востоке [Там же. С. 335]. О культурных влияниях «венедов-арийцев» на предков евреев задолго до Ф.Г.-Х. Нурутдинова писали русские националисты, в частности, В.Н. Емельянов. По его мнению, именно мифические предки славян дали назва- 
ние Палестине («Опаленный Стан»). Как отмечает В.А. Шнирельман, «Опаленный стан» - один из «терминов-маркеров» современных русских антисемитов-неоязычников, который позволяет безопасно общаться на волнующие их темы [23. С. 58, 59-61].

В конце концов после многочисленных миграций булгары, как и русы, оказываются «у себя дома», т.е. на современной территории проживания их потомков, что позволяет, с одной стороны, считать их автохтонами, с другой - связывать с великими, но территориально удаленными цивилизациями древности.

Миф об арийском происхождении булгар и их фантастических миграциях Ф.Г.-Х. Нурутдинов озвучивал в своем «методологическом» пособии по истории Татарстана [27. С. 16].

В.А. Шнирельман указывал, что Ф.Г.-Х. Нурутдинов пытался установить контакты с русскими националистами, в частности, им была опубликована статья в их газете «Дуэль» [3. Т. 2. С. 224]. В ней утверждалось, что булгары, как и русские, являются потомками волго-уральских арийцев («сакланов»), которые, в свою очередь, 15 тыс. лет назад смешались с пришлыми финно-уграми. От отюреченных угров сакланы якобы восприняли тюркский язык и стали называться булгарами [28]. Задокументированный факт сотрудничества с русскими националистами является еще одним доказательством в пользу того, Ф.Г.-Х. Нурутдинов в качестве источников своего мифотворчества использовал в том числе и славяно-арийский миф.

В 2010 г. увидела свет его новая книга, на этот раз с еще более фантазийной мифологией и упоминанием новых поддельных источников. Арийские предки булгар здесь уже не фигурировали, но, принимая во внимание предыдущие работы автора, своеобразным следом арийского мифа следует признать утверждение о том, что 22 июня (т.е. в период летнего солнцестояния) 14953 г. до н.э. в районе современного Болгарского городища (Спасский район Татарстана) было провозглашено «образование первого в мире государства людей - булгарской державы Идель» [29. С. 23].

Запредельную мифологию Ф.Г.-Х. Нурутдинова попытался облечь в наукообразную форму кандидат исторических наук, профессор Казанского государственного педагогического университета 3.3. Мифтахов (1938-2013). Защитивший в советское время посвященную левым эсерам кандидатскую диссертацию [30], а затем специализировавшийся на изучении работы коммунистов в системе судебно-следственных учреждений Татарии [31], в 1990-е гг. Зуфар Зайниевич обратился к древней и средневековой истории, результатом чего стал «Курс лекций по истории татарского народа», доведенный им до середины XVI в. [32, 33]. Опираясь на поддельную «Джагфар тарихи», 3.3. Мифтахов создал этноцентричный мифический нарратив, который в течение нескольких лет преподавался будущим учителям. Хотя предки булгар напрямую и не атрибутировались в качестве «арийцев», направления их миграций повторяли фантазии Ф.Г.-Х. Нурутдинова и русских националистов.

Согласно 3.3. Мифтахову, предками булгар были обитавшие в Волго-Уралье с незапамятных времен ираноязычные синдийцы, которые в IV тыс. до н.э. «разделились на три части и ушли по трем направлениям»: в Предкавказье; Алтай, Монголию и Северный Китай; и, наконец, третья группа, двигаясь «в сторону Месопотамии» через современный Туркменистан и Афганистан, оказалась на Иранском нагорье, которое «синдийиы назвали Арианой» [32. С. 20, 29-31]. После многочисленных исторических приключений (здесь и Шумер, и Вавилон, и Троя) булгары (сословие воинов, превратившееся в «этнос», что опять указывает на аналогии с арийцами) оказываются на «исторической родине» в Поволжье. Синдийцы 3.3. Мифтахова напоминают синдов В.И. Скурлатова, который в своей работе 1987 г. синдами называл один из кланов ариев, обитавших во II тыс. до н.э. вблизи «нынешних Анапы, Геленджика и Новороссийска». На своих колесницах часть синдов через Среднюю Азию достигла Индостана, основав там «великую индийскую иивилизацию», другая часть синдов «вместе с другими группами ариев» через Дербентский проход проникла в Месопотамию [24. С. 214]. Видимо, для 3.3. Мифтахова, так же как и для Ф.Г.-Х. Нурутдинова, сочинение В.И. Скурлатова послужило одним из источников собственного мифотворчества.

В социальной сети «ВКонтакте» существует группа с говорящим названием «Булгары-АРИИ». В ней на 1 сентября 2016 г. состояли 313 человек (в той же социальной сети в официальной группе «татаристского» Института истории им. Ш. Марджани АН РТ на то же время числилось 189 человек). Одна из тем обсуждений группы называлась «Булгары - Арии?». Под арийцами многие участники дискуссии понимали не этноним, а социальный термин, «обозначение свободного благородного воина», потомка «солнечного народа». Кроме того, постулировалось, что «“арий” как рыцарь не есть исключительно иранский термин. Тюркская воинская культура также имеет прямое отношение к арийскому феномену» [34].

Как видно из вышеизложенного, арийский миф вызвал интерес у части татарстанских историков-булгаристов и сочувствующей им относительно немногочисленной аудитории. Период конца 1980-х и 1990-е гг. характеризовался борьбой «булгаристов» и «татаристов», решался вопрос, какой из проектов возьмет на вооружение руководство Татарстана в качестве официально признанной идеологемы. «Булгаристская» концепция явно проигрывала из-за автохтонизма и отсутствия «великих» предков. Путем «добавления» элементов арийского мифа в орбиту булгарского этнонационализма оказались вовлечены яркие эпизоды истории Евразии, которые вполне могли составить конкуренцию «татаристской» Золотой Орде.

Однако и сами «татаристы» (сторонники версии о том, что современные татары - потомки населения Улуса Джучи) не прочь использовать «арийство» в своих интересах. В их распоряжении более значительный, нежели у «булгаристов», административный ресурс - большинство сотрудников созданного в 1996 г. Института истории им. Ш. Марджани АН РТ, включая директора, являются «татаристами». В первом томе «Истории татар» (фундаментальном семитомном издании этого института) интерес к арийству проявился в полной мере. Материал тома структури- 
рован таким образом, что одними из предков современных татар оказались жившие в Волго-Уралье в эпоху бронзы индоиранские племена. Именно с них начинается нарратив татарской истории. Согласно петербургскому археологу В.С. Бочкареву, к началу II тыс. до н.э. складывается волго-уральский очаг культурогенеза, в рамках которого племенные союзы ариев консолидируются «в этническом отношении» и создают свои предгосударственные образования. Впоследствии они сыграли крупную роль в древней истории Передней и Средней Азии, Индостана. Автор наделяет волго-уральских ариев культуртрегерскими чертами и констатирует, что путем миграций и военных походов «волго-уральские достижения и новшества сравнительно быстро распространились по огромной территории» [35. С. 46]. Индоиранское население Волго-Уралья позиционируется создателями обширной культурной провинции от Южной Сибири и Средней Азии на востоке и юго-востоке до Поднепровья и Северного Кавказа на западе и югозападе [35. С. 46]. В.С. Бочкарев, локализуя арийцев в Волго-Уралье (на что в науке есть и другие точки зрения, их перечень см.: [3. Т. 1. С. 189-190]) и открывая этим утверждением повествование о древнейших этапах истории татар, фактически превращает последних в автохтонов региона.

За статьей В.С. Бочкарева в первом томе «Истории татар» следует публикация известного петербургского востоковеда С.Г. Кляшторного (1928-2014) с говорящим названием «Страна ариев». Автор профессионально сопоставляет иранские и индийские письменные источники с материалами археологических культур Восточной Европы, Сибири и Средней Азии, однако из общего контекста тома следует, что в дискурс истории татар включается «арийский компонент», в том числе знаменитый Аркаим [36].

С.Г. Кляшторный заканчивает свою статью констатацией того, что «преемниками ариев в Великой Степи стали их отдаленные потомки - скифы, саки и савроматы»» [Там же. С. 76], которым посвящена 2-я глава «Истории татар», подготовленная известными специалистами Д.С. Раевским (1964-2004), С.Г. Кляшторным и В.А. Ивановым [37]. Лишь во второй части тома уделяется внимание собственно тюркским народам и государственным образованиям Евразии эпохи древности.

Упомянутых авторов, которые являются признанными в научном мире профессионалами, трудно заподозрить в симпатиях к арийскому мифу. Скорее всего, «арийским началом» «История татар» обязана одному из главных редакторов тома - на тот момент Советнику Президента Татарстана по политическим вопросам, директору Института истории им. Ш. Марджани АН РТ, кандидату философских наук (в 2009 г. стал доктором исторических наук) и физику по базовому образованию Р.С. Хакимову. Видимо, знакомство с основными сюжетами арийского мифа, желание найти автохтонных престижных предков (прафинноугры на эту роль не подходили) и в то же время боязнь обвинений в мифологизаторстве заставили идеолога пойти на сложный маневр - научные статьи приглашенных авторитетных специалистов с «удобными» точками зрения оказались вплетенными в общую канву мифического повествования. Этот ход позволил самому Хакимову в том же томе констатировать, что предки татар сформировались «на базе культурь скифских и других племен и народов» [38], тем самым открывая возможности для актуализации по «ретроспективной цепочке» «арийских предков». Однако на сегодняшний день потребности в престижных арийцах и их «предгосударственных образованиях» у татарстанских идеологов нет («достаточно» Золотой Орды), поэтому в официальной риторике они пока не упоминаются.

Если арийский миф встречается в татарстанских академических изданиях, то его появление в публикациях жанра «фольк-хистори» вполне ожидаемо. Так, В.М. Ланцов и К.М. Зиятдинов считают, что предками казанских татар была часть русов-арийцев, проживавших в районе Аральского моря. Доказательства, по их мнению, заключаются в том, что, во-первых, «казанские татары - единственная европеоцная раса в районе Арал-Каспий, родиной которых после Севера стали берега Аральского моря», во-вторых, на артефактах, связанных с Волжской Булгарией, находят изображения свастики и шестиконечной звезды (последняя трактуется ими как арийский языческий символ единства мужского и женского начал), и, в-третьих, градостроительные характеристики булгарских городов якобы схожи с «арийскими городами» [39. С. 19, 20].

Авторы отмечают «сильное и верховное» влияние культуры предков казанских татар на культуру будущих тюркских народов. О высоком их статусе среди арийцев якобы говорит та связующая роль, которую они играли между «ядрами» проживания русов в Средней Азии, в будущих Иране и Турции, Месопотамии, на Аравийском полуострове, с одной стороны, и с русами в Южной Сибири, на Южном Урале и Причерноморье - с другой.

В конце концов, являвшиеся «аральским ядром русов» предки казанских татар в конце I тыс. н.э. вернулись в Восточную Европу и образовали Булгарское государство, а затем Казанское ханство, позиционируемое предшественником современного Татарстана [Там же].

Отождествление предков казанских татар с арийцами и в целом обращение к арийскому мифу в данном случае имеют явно компенсаторную функцию. Авторы сами признаются, что стремятся опровергнуть распространенное мнение о предках казанских татар как «кочевниках» и «язычниках» и посредством «арийства» подчеркивают их значительную роль в развитии человечества [Там же].

Элементы арийского мифа можно проследить на страницах татарстанской прессы. Главный редактор популярной казанской газеты «Звезда Поволжья» Рашит Ахметов, воодушевившись «древней народной музыкой Тибета» и творчеством Н. Рериха, публично задумывается о том, что «может, действительно скромные татары и есть те самые загадочные арийц̧ы. По крайней мере, Шаймиев (Президент Татарстана в 1991-2010 гг. - А.О.) очень похож на тибетского ламу. Есть в конце конияов и теории реинкарнацииџ [40. С. 2]. Некоторые российские политические деяте- 
ли, видимо, стремясь выстроить доброжелательные отношения с татарстанской политической элитой, видят в предках татар арийцев, отождествляя последних с тюрками. Например, депутат Государственной Думы Владимир Колесников, выступая на презентации книги своего коллеги - депутата от Татарстана Фатиха Сибагатуллина, заявил, что 2500 лет назад в Индию «пришли люди-наги, их тотемом был змей с равносторонним крестом из золота. Это были тюрки, создавшие Солнечную династию. Единобожие возникло на базе тюркских богослужебных сводов» [41. С. 2]. Нетрудно догадаться, что здесь идет речь об арийцах, свастике и попытках связать свастику с христианским крестом. В представлении В. Колесникова именно тюрки (они же арийцы), а не греки, привнесли в Россию единобожие и символику креста.

Кроме булгарского и татарского, элементы арийского мифа можно обнаружить и в риторике еще одного татарстанского национализма - кряшенского. Кряшены - небольшой, в основном православный, тюркоязычный народ, проживающий в Татарстане, Челябинской области (нагайбаки), Удмуртии, Чувашии и т.д. С 1920-х гг. они официально включались в состав татар (так называемые крещеные татары). В 1990-е гг. стало усиливаться кряшенское самосознание, появились активисты, требовавшие признать кряшен самостоятельным народом. Дискуссия обострилась в 2002 г. во время Всероссийской переписи населения. Если бы кряшены в переписных листах фигурировали «отдельным» народом, то это бы «сократило» количество татар в Татарстане и поставило бы под вопрос само существование республики как субъекта федерации. Наряду с прочими мероприятиями Академией наук РТ в тот год была организована конференция «Цивилизационные, этнокультурные и политические аспекты единства татарской нации», участники которой, в основном на историческом материале, доказывали, что крещеные татары являются частью татар и начали формироваться лишь после завоевания Казанского ханства Иваном IV Грозным (1552 г.) и начала принудительного крещения местного населения [42]. Данная позиция была характерна для большинства татарских историков 1990-2000-х гг. и ныне в Татарстане она остается официальной.

Кряшенские же историки и публицисты пытаются доказать, что кряшены образовались значительно раньше середины XVI в. и в поисках предков обращают свои взоры в седую, в том числе и «арийскую», древность. В 1993 г. (т.е. практически одновременно с «Джагфар тарихи» булгариста Ф.Г.-Х. Нурутдинова) было опубликовано литературно-публицистическое произведение одного из кряшенских лидеров Татарстана, кандидата исторических наук [43] М.С. Глухова (1937-2003) «Судьба гвардейцев Сеюмбеки: Неформальный подход к еще неписаным страницам истории» [44]. Эта работа свидетельствовала об эрудиции автора, однако выбираемые им из научной литературы данные интерпретировались весьма вольно, фактически они подгонялись под уже заданные выводы, что позволяет определить жанр книги как мифическое повествование.

М.С. Глухов отрицал отождествление названий «крещеные татары» и «кряшены». Используя часто применяемый при мифизации истории «метод» созвучий, он «обнаружил» предков кряшен в керчинах, которые в начале нашей эры обитали в Керии стране, расположенной в горной системе Куньлунь. Ссылаясь на работы Н.М. Пржевальского и Г.Е. ГрумГрумжимайло, М.С. Глухов связывал керчинов с арийцами, выходцами из Северной Индии [44. С. $197-$ 198] (в одной из статей предки кряшен были даже отождествлены с обитателями легендарной Шамбалы, «откуда будто бы вышли предки всех индоевропейских народов») [45]. Фантазии М.С. Глухова об арийском происхождении предков кряшен развивает В. Максимова, которая пытается связать находящийся в Челябинской области известный памятник эпохи бронзы Аркаим с проживающими там же кряшенаминагайбаками [46], добавляя тем самым новое содержание в обширную «аркаимскую» мифологию (подробнее о ней см.: [47-50]).

Использование арийского мифа в кряшенском национализме имеет инструментальный характер и направлено, прежде всего, на обоснование отличного от татар «исторического пути».

Арийство в Татарстане циркулирует и в дискурсе русского национализма. Поклонником арийского мифа стала доктор исторических наук, профессор, заведующая кафедрой истории Казанского национального исследовательского технического университета И.А. Гатауллина. Учитывая, что перед нами профессиональный историк, чьи учебные пособия, повествующие о славянах-арийцах, рекомендованы для студентов, на взглядах этого автора следует остановиться подробнее. Показательны вехи её биографии, маркирующие путь от коммунистического идеолога до пропагандиста Гипербореи. И.А. Гатауллина (Апайчева) училась на историко-филологическом факультете Казанского государственного университета им. В.И. УльяноваЛенина, работала в комитете комсомола Казанского инженерно-строительного института (КИСИ) в качестве освобожденного секретаря по идеологической работе с молодежью. В 1990 и 2009 гг. соответственно защитила кандидатскую и докторскую диссертации по истории Среднего Поволжья 1920-30-х гг. [51-54].

Еще в 2001 г. увидела свет её статья, посвященная проблемам межкультурной коммуникации. В ней Ирина Алексеевна признавала «огромные различия в иенностных ориентащиях различныхх народов» [55. С. 27] и соглашалась с мнением, что «глубинной основой современной политики является национал-социалистическая структура, когда субъектами истории выступают отдельные государства, поддерживающие сочиальный мир внутри своих грании и жесткого преследуюшие интересы собственной нащии вплоть до конфликтов с интересами других наций» [Там же. C. 27]. О тенденциях мировых глобализационных процессов, постепенно стирающих государственные границы, И.А. Гатауллина не упоминала, но зато высказывала симпатии традиционным культурам, которым было свойственно «гармонизирующее видение человека и космоса» [55. С. 28]. Наконец, она призывала человека признать «себя существом слабым», «превратиться в песчинку», чтобы «заново научиться вписываться в естественные цииль биосферы, так, 
как это происходило в эпоху неолитической революųии» [Там же. С. 29]. Таким образом, И.А. Гатауллина четко обозначила свою принадлежность к так называемым русским традиционалистам (подробнее о традиционализме см.: [56]).

«Традиционалистская методология», как известно, базируется на признании некой «изначальной традиции», существовавшей в эпоху древних сакральных цивилизаций, после упадка которых сохранявшейся в кругу «посвященных». Элементы этой традиции якобы можно обнаружить в живом наследии различных культов и религий, отсюда повышенное внимание к мифу в ущерб научным фактам. Специалисты признают традиционализм надполитической идеологией, идущей «от Юлиуса Эволь, Рене Генона и через франиузских

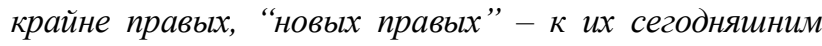
последователям» [57]. Русские традиционалисты не столько возрождают «живую традицию», сколько перестраивают и перекраивают её в своих интересах, зачастую являясь, например, интеллектуальными вдохновителями скинхедов [Там же]. Представители русского традиционализма отрицают официальные учебники истории и устоявшиеся версии исторической национальной идентичности. Они пытаются конструировать новую идентичность, важными элементами которой являются мифы евразийства, арийства, гиперборейства и т.д. [Там же]. По этому «методологическому» пути пошла и И.А. Гатауллина.

В 2013 г. была опубликована её статья «Протоистория славян как проблема самоидентификации российского общества» [58]. Ирина Алексеевна констатировала, что русские нуждаются в «самоидентификации», которую академическая наука обеспечить не может. Главная причина этого, по мнению И.А. Гатауллиной, заключалась в отсутствии письменных источников по древнейшей истории славян [58. С. 6]. Между тем современной археологической наукой накоплен огромный корпус источников, иллюстрирующий во всем многообразии материальную и духовную жизнь древних славян, их предков и соседей. Вместо изучения трудов археологов и их популяризации И.А. Гатауллина призывала обратиться к некоему культурологическому контексту темы, «в основе которого лежит понятие исторической памяти» [Там же. С. 7]. Указывая на эвристический потенциал постмодернистской методологии, Ирина Алексеевна предлагала восстановить «медиум бытия истории» через «праязык и миф». Подходящим мифом для пропаганды была выбрана гиперборейская, или полярная, версия «происхождения не только славянского этноса, но человечества, кольбель которого определяется в акватории Ледовитого океана, точнее, на севере России» [Там же]. Далее в стиле славянского фэнтези [59] она повторяет основные сюжеты гиперборейского мифа и упоминает ряд «ученых», чьи построения были подвергнуты суровой критике специалистами, в частности В.А. Шнирельманом [60]. Например, Ирина Алексеевна ссылается на известного русского расиста П. Тулаева [58. С. 10, 12]. В 1995 г. он стал одним из организаторов праворадикального журнала «Наследие предков» (название явно было заимствовано у германской научно-оккультной организации, идеологом которой был Г. Вирт (также фигурирующий в публикациях И.А. Гатауллиной), а руководил лично Г. Гиммлер). Затем П. Тулаев со своими единомышленниками учредил журнал «Атеней», на страницах которого пропагандировались расовые идеи [61. С. 172-173]. Много места уделялось и Гиперборее якобы прародине славянской арийской расы. По мнению немецкого журнала «Nation\&Europa», издатели «Атенея» являлись мозговым штабом праворадикального движения в России [62]. «Атеней» стал собирать вокруг себя скинхедов [61. С. 348]. В 2003 г. в Москве состоялась ознакомительная встреча отечественных расистов с зарубежными «коллегами». Россию представлял в том числе и П. Тулаев, а среди иностранных гостей были «бывший Великий дракон ку-клукс-клана Дэвид Дюк и известный ревизионист Холокоста швейцареи Юрген Граф» [Там же. С. 232]. В 2007 г. П. Тулаев был ведущим на проходившей в Москве Международной конференции борцов за «белую расу». На этом мероприятии выступали известные зарубежные антисемиты и даже бывший эсэсовец, вспоминавший, как в 1945 г. защищал Берлин от советской армии [Там же. С. 234]. В 2010 г. Королёвским городским судом журнал «Атеней» был признан экстремистским [63].

В конце статьи И.А. Гатауллина призывает к тому, «чтобы академические умь отказались от понятия “лженаука”, с которой отождествлялась гиперборейская версия происхождения славянского этноса» [58. С. 12]. Однако научные основания для такого отказа названы не были.

Главные положения своей статьи И.А. Гатауллина почти дословно воспроизвела в вышедшем в 2014 г. вузовском учебнике истории [7. С. 29-31, 40, 42-45], на что мне пришлось откликнуться пространной рецензией $[64,65]$. Чтобы не повторяться, отмечу лишь те концептуальные идеи, которые Ирина Алексеевна пытается донести до студентов. Рассказ о «теории и методологии исторической науки» в учебнике начинается с известного расиста XIX в. Ж.-А. Гобино (1816-1882) и описания того [7. С. 15], что специалистами признано расистской версией теории цивилизаций [66. С. 252-257]. Фактически дается положительная оценка полицентризму - идее о разных местах происхождения человеческих рас [7. С. 31], что с высокой долей вероятности может подвести к популярному сегодня у русских националистов и давно отвергнутому наукой полигенизму [67] - гипотезе о том, что человеческие расы - это разные биологические виды, произошедшие от разных видов обезьян. По ходу учебника критикуется христианство («рабы $u$ религия рабов» [7. С. 42]), разрушившее античный языческий мир и оборвавшее связь Руси с «Гиперборейской цивилизацией» [Там же. С. 44]. В качестве «ученых», исследовавших гиперборейскую (а заодно и арийскую) проблему, И.А. Гатауллина приводит авторов с более чем сомнительной репутацией: радикального индийского националиста Б.-Г. Тилака (1856-1920); близкого к СС немецкого мистика Г. Вирта (1885-1974), Р. Генона (1886-1951), чьи идеи «нашли последователей в Италии, Германии и Румьнии и были взяты за основу оккультными фашист- 
скими течениями» [68. С. 227]; А.Г. Дугина - современного отечественного философа, политолога и общественного деятеля, идеи которого, по мнению признанных специалистов в этом вопросе, имеют точки соприкосновения с фашизмом [68; 69. С. 147-148], в том числе в сюжетах «арийства» и Гипербореи [61. С. 220]; наконец, профессионального философа и археолога-дилетанта В.Н. Демина (1942-2006), известного своими фантазиями о гиперборейских памятниках на Севере европейской части России (подробнее о несостоятельности его «археологических открытий» см.: [23. С. 29-32]).

Из учебника тысячи студентов КНИТУ-КАИ узнают о гиперборейском праязыке [7. С. 40-41]; более древних, чем египетские, пирамидах русского Севера; гиперборейских летательных аппаратах, на которых можно было совершать межконтинентальные перелеты [Там же. С. 44]; об ариях, предках славян, мигрировавших в своё время из Гипербореи, в том числе «в направлении Индии, Египта и Шумера» [Там же. С. 30, 43]; едином славянском «пранароде», говорившем на общем для всех славян языке, который (И.А. Гатауллина приводит цитату из текста В.Н. Демина) «берет свое начало от одного отияа Славы, откуда и славяне» [Там же. С. 42]; о мифических славянских первопредках Русе и Словене [Там же. С. 43] и о славянах, участвовавших в Троянской войне [Там же].

Политические коннотации своих построений И.А. Гатауллина не скрывает. По её мнению, признание славян потомками гиперборейцев лишает их «варварской функции» и ставит в один ряд с греками и римлянами, носителями «культурной миссии» [Там же. С. 30]. Российская северная цивилизация признаётся «промежуточным звеном» между Востоком и Западом, что, по мнению Ирины Алексеевны, заставляет переосмысливать историю мира, начало которой якобы лежит на севере Евразийского континента.

В вузовском учебнике И.А. Гатауллина фактически воспроизвела многие воззрения современных русских неоязычников-родноверов (подробнее о них см.: $[23,70-73])$.

Следует признать, что в условиях борьбы России за богатый полезными ископаемыми арктический шельф граничащие с расизмом фантазии о северной прародине славян-арийцев вполне могут стать актуальными для отечественного политического дискурса. Если российские чиновники будут поддерживать гиперборейский миф, то многие его «разработчики» (Р. Генон, Г. Вирт, А.Г. Дугин, П. Тулаев и др.) станут известны широкому кругу студентов, школьников и обывателей, что, по моему мнению, сделает угрозу распространения в России крайне правых идей еще более реальной.

И.А. Гатауллина начинает пользоваться популярностью у адептов гиперборейского мифа. Они увидели в её публикациях выход на вузовскую аудиторию и академическую легитимацию своих фантазий, и поэтому в ответ на мою критику пытаются защищать своего неожиданного союзника: «Мужества вам, профессор Ирина Алексеевна Гатауллина. Пожалуйста, не сомневайтесь, историческая правда за вами. Каких бы спесивых, плохо информированных наци- стов, для которых Гипербореи, как древней Руси, не существовало в приничие, вам и не приписывали бы в “друзья”» [74].

Критика сделала последующие публикации И.А. Гатауллиной более осторожными, но от гиперборейского мифа она, похоже, отказываться не собирается. Одна из её последних на данный момент статей, посвященных Гиперборее, увидела свет в сборнике материалов прошедшей 3-4 октября 2016 г. в стенах Института всеобщей истории РАН конференции «История, память, идентичность: теоретические основания и исследовательские практики» [75]. Отождествляя себя с «авторитетной академической наукой», И.А. Гатауллина констатирует популярность гиперборейской тематики и выводит из этого необходимость научного осмысления проблемы. Между тем зарождение, развитие и распространение мифов об Атлантиде, Гиперборее и других несуществовавших материках-цивилизациях уже давно анализируются специалистами (подробнее см.: [76-78]), тогда как Ирина Алексеевна, по сути, предлагает не столько изучать миф, сколько пытаться сомнительными, с точки зрения науки, способами онтологизировать его содержание. Она констатирует существование «целой отрасли научного знания - атлантологии, в арсенале которой 6 тыс. томов информации. Гиперборея по сравнению с Атлантидой представляет собой локальную историю» [75. С. 94]. Где опубликованы эти тысячи томов, является загадкой, и в современной России атлантология (так же как и «гипербореология» [4. C. 25]) - это всего лишь одна из многих псевдонаук.

Построения И.А. Гатауллиной вступают в противоречие друг с другом, когда, с одной стороны, она критикует «модернистскую парадигму», которая «вытеснила гиперборейскую, или полярную, гипотезу на задворки академической науки» [75. С. 94] (из-за элементарного отсутствия источников), с другой - в духе модерна, частью которой является современная наука с её методологией и обязательной опорой на факты, она пытается «доказать» существование Гипербореи, ссылаясь на «исследования» российских «ученых» в акватории Северного Ледовитого океана [Там же. С. 96]. В результате конструируются мифические «причинноследственные связи, которые», якобы, «выстраивают исторический прочесс, трансформирующий Гиперборейский миф в научную гипотезу» [Там же].

В рассматриваемой статье уже нет упоминаний Р. Генона, Г. Вирта, А.Г. Дугина и других неоднозначных авторов, зато И.А. Гатауллина сосредоточивается на рассуждениях астрофизика А.М. Чечельницкого о Волновой Космогеономии, смене полюсов вращения Земли, Космогенном Шоке, Атлантиде и Гиперборее в районе современной Аляски, Беринговом проливе как Геракловых Столпах и Дальнем Востоке, как «Древнейшей ПраРодине - в широком смысле этого слова» [Там же].

И.А. Гатауллина опять не пытается скрывать связь своих конструкций со злободневной политикой. Она прямо пишет об «украинском факторе», допускающем «изменение представления о славянском единстве» [75. С. 94]. Иными словами, Древнерусское государство с центром в Киеве сегодня «не пригодно» 
для «идеологической эксплуатации», и его место якобы вполне может занять легендарная Северная Прародина на Дальнем Востоке (хотя, например, представителям США вряд ли понравится включение в состав этого мифического образования Аляски).

Увлечение традиционной культурой привело И.А. Гатауллину к скепсису в отношении научного знания и формирования рациональных основ идентичности. По мнению Ирины Алексеевны, миф дополняет ограниченность эмпирического опыта. Однако это «методологическое положение» открывает широкие просторы для мифизации и фальсификации истории, которые, в свою очередь, могут стать «объяснением» и «обоснованием» авторитаризма, расизма и ксенофобской внешней политики. Рассуждения Ирины Алексеевны удивительным образом напоминают мысли другого «поклонника» Гипербореи и широко расселившихся из её пределов арийцев - одного из главных идеологов Германии 1930-х - первой половины 1940-х гг. А. Розенберга (1893-1946). В своем произведении «Миф XX века» [79], не учитывая должным образом научные факты, подбирая их по своему усмотрению, он конструировал «миф крови», цель которого состояла в предоставлении ответа на заданный вопрос, причем ответ должен был соответствовать интересам «органического единства», т.е. «народа» (подробнее см.: [60]). Кроме того, некоторые утверждения в написанных И.А. Гатауллиной главах учебника «История» почти дословно повторяют отдельные места из текста «Мифа ХХ века» (см. соответственно [79. С. 21-22] и [7. С. 30, 42-43]; подробнее, с приведенными цитатами, см.: $[64,65])$.

В своих публикациях на страницах татарстанских изданий славянский вариант арийско-гиперборейского мифа последовательно пропагандирует журналистка Галина Зайнуллина. Рассказывая, казалось бы, о далеких от «арийства» сюжетах, она, как бы «между делом» упоминает об арийцах, Гиперборее, Шамбале, «гондванической расе» или подводит своего респондента под нужные ей выводы [80-84]. Следует признать, что истинный смысл этих вставок и полунамеков понятен только «посвященным», а также ученым, исследующим арийский миф. Для большинства же читателей, и скорее всего, редакторов изданий, в которых печатается Г. Зайнуллина, эти пассажи кажутся странноватыми, но безобидными историкоэзотерическими отступлениями.

Более массовому распространению арийского мифа, на мой взгляд, может способствовать широкая популяризация творчества казанского художника Константина Васильева (1942-1976). В.А. Шнирельман отмечал связь сюжетов его картин с арийским мифом и русским неоязычеством [3. Т. 1. С. 278, 300; T. 2. С. 72]. Творчество этого художника пользуется популярностью у русских православных националистов (несмотря на наличие у К. Васильева картины «Илья Муромец побеждает христианскую чуму») и родноверов.

В 2013 г. в Казани на местном «Арбате» (пешеходной улице Баумана - самой привлекательной для туристов) открылся Музей Константина Васильева. До этого Галерея художника располагалась в одном из «спальных» районов города. Музей строился под патронатом мэра Казани и комитета земельных и имущественных отношений [85]. В фойе посетитель может приобрести как православную, так и языческую литературу. В неформальном разговоре с экскурсоводом мне удалось выяснить, что музей пользуется популярностью у русских неоязычников. По его словам, музей специально посещала директор томского Первого музея славянской мифологии Ольга Павлова (подробнее об этом музее см.: [86]). Среди отзывов посетителей о Музее Константина Васильева встречаются следующие (орфография и стилистика сохранены): «Нет правда, откуда у Васильева такое чувство русской души, какой мифологией создань сюжеты этих картин. Они древние и языческие, идущие от природын.. они для меня, как иконь и на них надо просто смотреть и думать о хорошем» [87]; «место достаточно маргинальное - альтернативная история, арии и прочая фоменковщчина» [88]; «В казанском музее вы сможете понять, что именно в таких художниках и картинах жива наша великая Pycb» [89].

Проанализированный материал позволяет сформулировать ряд выводов о специфике распространения арийского мифа в Татарстане.

Связанное с мотивами «истоков» и «прародины» «арийство» обнаруживается во всех более или менее массовых национализмах региона - татарском, булгарском, кряшенском и русском. Арийский миф пропагандируют не только историки-дилетанты (Ф.Г-Х. Нурутдинов, М.З. Закиев, Р.С. Хакимов, Г. Зайнуллина, В.М. Ланцов В.М. и К.М. Зиятдинов), но и «остепененные» профессионалы (3.3. Мифтахов, М.С. Глухов, И.А. Гатауллина). Заинтересовавшиеся арийским мифом историки защищали свои кандидатские и докторские диссертации по истории ХХ в., более того, их с полным основанием можно назвать бывшими коммунистическими идеологами. Скорее всего, обращение в 1990-2000-е гг. к древней истории было связано с осознанием изменений идеологических потребностей правящей (как федеральной, так и региональной) элиты. Кроме этого, нельзя не учитывать особенности социализации самих авторов, выросших в специфических условиях деревни или городского двора и, безусловно, впитавших определенные иррациональные мировозренческие («жизненные») постулаты и модели поведения. После официальной инициации в форме обучения, например, в классическом университете [90], защиты диссертаций по узкоспециальным темам, получения ученых степеней и соответствующего статуса, они позволяли себе делиться с окружающими тем «сокровенным», что якобы находится вне пределов понимания «официальной науки». Можно говорить об определенном двоемыслии, когда в сознании уживаются и ученый, и обыватель со своей «житейской мудростью».

Построения татарстанских апологетов «арийского мифа» направлены, по моему мнению, не столько на завоевание «умов масс», сколько на привлечение внимания высокопоставленных чиновников, которые потенциально могли бы выступать в качестве «патрона» (вспомним дискуссии между «булгаристами» и 
«татаристами», а также пристальное внимание И.А. Гатауллиной к изменениям политической конъюнктуры). Прагматическая цель в представлении авторов, видимо, оправдывает осознаваемые ими фантастичность и непрофессионализм своих исторических конструкций. Если последние станут частью идеоло- гического дискурса, то академическая критика станет «не страшна», да и тех, кто рискнет деконструировать миф, найдется не слишком много. Специфика (со)организации российского, особенно регионального, научного сообщества может сделать вполне реальной академическую легализацию арийского мифа.

\section{ЛИТЕРАТУРА}

1. Низамитдинзода X. Год со свастикой? 2006 год в Таджикистане объявлен Годом арийской культуры. 14.02.2006 // ЦентАЗИЯ. URL: http://www.centrasia.ru/newsA.php? st=1139908440 (дата обращения: 1.09.2016).

2. Повелитель арийцев. Чем обернулся культ личности в Таджикистане. 5.05.2016 // STAN RADAR. URL: http://www.stanradar.com/ news/full/20679-povelitel-arijtsev-chem-obernulsja-kult-lichnosti-v-tadzhikistane.html (дата обращения: 1.09.2016)

3. Шнирельман В.А. Арийский миф в современном мире. М. : Новое литературное обозрение, 2015. Т. 1-2. 536 с.

4. Жарчинская К.А. Славяно-арийский миф в историческом сознании российских традиционалистов : дис ... канд. ист. наук. Томск, 2015. $151 \mathrm{c}$.

5. История России с древнейших времен до наших дней / А.Н. Боханов, Л.Е. Морозова, М.А. Рахматуллин, А.Н. Сахаров, В.А. Шестаков: под ред. А.Н. Сахарова. М. : АСТ, 2016. 1744 с.

6. Юрьев А.И. История Отечественной культуры : учеб. пособие. М. : Русское поле, 2015. 208 с.

7. История : учеб. / под ред. Д.К. Сабировой и И.А. Гатауллиной / общ. ред. Д.К. Сабировой. М. : Кнорус, 2014.325 с.

8. Фаттахов Ф.Ш. Прототюрки: географические представления, боги и язык. Казань : Казан. ун-т, 2013.440 с.

9. Хайруллин М.Б. (доктор филологических наук, профессор). Пути решения назревших проблем // Фаттахов Ф.Ш. Прототюрки: географические представления, боги и язык. Казань : Казан. ун-т, 2013. С. 5-8.

10. Закиев М.З. Происхождение тюрков и татар. М. : ИНСАН, 2003. 496 с.

11. Шнирельман В.А. От конфессионального к этническому: булгарская идея в национальном самосознании казанских татар в ХХ в. // Вестник Евразии. 1998. № 1-2. С. 137-159.

12. Габдурахманов Х.Г., Сибгатуллин Р.Г. Заявление Казанского Меджлиса булгарской общины (Казань, 20 августа 1992 г.) // Нурутдинов Ф. Булгарский вопрос. Оренбург : Редакция Вестника «Булгария», 1993. С. 55-62.

13. Нурутдинов Ф.Г-Х. Спасите булгар от дискриминации (И.о. Президента РФ г-ну В.В. Путину) // Звезда Поволжья. № 8(11). 2-6 марта 2000 г. С. 2.

14. Открытое письмо // Звезда Поволжья. № 9 (113). 7-13 марта 2002. С. 3.

15. Закиев М.З. История татарского народа (Этнические корни, формирование и развитие). М. : ИНСАН, 2008.560 с.

16. Фаттах Н. Язык богов и фараонов. Казань : Татар. книж. изд-во, 1999. 488 с.

17. Фаттах Н. Древние языки мира в сопоставлении с татарским (историко-лингвистическое исследование). Казань : Идель-Пресс, 2008. $616 \mathrm{c}$.

18. Шамилоглу Ю. «Джагфар тарихы». Как изобреталось булгарское самосознание // Фальсификация исторических источников и национальные истории: материалы Круглого стола 17 сентября 2007 г. М. : Ин-т востоковедения РАН, 2007. С. 35-39.

19. Нурутдинов Ф.Г.-Х. Булгары и мировая цивилизация // Бахши Иман. Джагфар Тарихи (История Джагфара). Т. 1. Оренбург : КОПФ «Оренбург-пресс-контакт»; Редакция вестника «Булгария», 1993. С. 324-347.

20. Скурлатова О. Загадки «Велесовой книги» // Техника молодежи. 1979. № 12. С. 55-59.

21. Щербаков В. Тропой Трояновой // Дорогами тысячелетий : сб. ист. очерков и ст. / предисл. А. Смирнова. М. : Молодая гвардия, 1987. C. 161-202.

22. Скурлатов В.И. След светоносных // Тайны веков / под ред. В. Суханова. М. : Молодая гвардия, 1977. Кн. 1. С. 331.

23. Шнирельман В.А. Русское родноверие: неоязычество и национализм в современной России (Серия «Диалог»). М. : Изд-во ББИ, 2012. xiv $+302 \mathrm{c}$.

24. Скурлатов В.И. Этнический вулкан // Дорогами тысячелетий / под ред. А. Смирнова. М. : Молодая Гвардия, 1987. Кн. 1. С. 203-224.

25. Щербаков В.И. Все об Атлантиде. М. : Общество по изучению тайн и загадок Земли. Ларге, 1990. 224 с.

26. Щербаков В.И. Асгард - город богов. М. : Молодая гвардия, 1991. 254 с.

27. Нурутдинов Ф.Г.-Х. Родиноведение (Методологическое пособие по истории Татарстана) / ред. Ф.В. Салихова. Казань : Татар. газет.журн. изд-во, 1995. 232 с.

28. Нурутдинов Ф.Г. Мы - булгары // Официальный сайт газеты «Дуэль». 27.01.1998. № 2(49). URL: http://www.duel.ru/199802/?2_4_1 (дата обращения: 15.06.2016).

29. Нурутдинов Ф.Г.-Х. Болгар тарихи. Казань : РИЦ, 2010. 284 с.

30. Мифтахов 3.3. Эволюция социалистов-революционеров и тактика большевиков по отношению к эсеровской партии в период первой русской революции : дис. ... канд. ист. наук. Казань, 1968. 241 л.

31. Мифтахов 3.3., Мулюков М.А. Борьба коммунистов Татарии за укрепление диктатуры пролетариата в первые годы советской власти: (Из опыта работы коммунистов в системе судебно-следственных учреждений). Казань : Изд-во Казан. ун-та, 1980. 216 с.

32. Мифтахов 3.3. Курс лекций по истории татарского народа. Казань: Казан. гос. пед. ун-т, 1998. 488 с.

33. Мифтахов 3.3. Курс лекций по истории татарского народа (1225-1552 гг.) / под общ. ред. А.Н. Хузиахметова. Казань : Казан. гос. пед. ун-т, 2002. $551 \mathrm{c}$.

34. «Булгары-АРИИ» // Группа в социальной сети «ВКонтакте». URL: https://vk.com/topic-41300658 27241362 (дата обращения: 15.08.2016).

35. Бочкарев В. Волго-Уральский регион в эпоху бронзы // История татар. Т. I: Народы степной Евразии в древности / гл. ред.: М. Усманов, Р. Хакимов ; науч. ред. С. Кляшторный ; отв. секретарь: И. Загидуллин ; ред.: Б. Хамидуллин. Казань : Рухият, 2002. С. 46-68.

36. Кляшторный С.Г. Страна ариев // История татар. Т. І: Народы степной Евразии в древности / гл. ред.: М. Усманов, Р. Хакимов ; науч. ред. С. Кляшторный ; отв. секретарь: И. Загидуллин ; ред.: Б. Хамидуллин. Казань : Рухият, 2002. С. 69-76.

37. История татар. Т. І: Народы степной Евразии в древности / гл. ред.: М. Усманов, Р. Хакимов ; науч. ред. С. Кляшторный ; отв. секретарь: И. Загидуллин ; ред.: Б. Хамидуллин. Казань : Рухият, 2002. 552 с.

38. Хакимов Р.С. История татар: взгляд из ХХІ в. // История татар. Т. I: Народы степной Евразии в древности / гл. ред.: М. Усманов, Р. Хакимов ; науч. ред. С. Кляшторный ; отв. секретарь: И. Загидуллин ; ред.: Б. Хамидуллин. Казань : Рухият, 2002. С. 3-11.

39. Ланцов В.М., Зиятдинов К.М. Очерк о развитии цивилизации славян, казанских татар и других арийцев. Казань : Новое знание, 2006.76 с.

40. Ахметов Р.Р. От Атиллы до президента // Звезда Поволжья. № 45. 3-9 декабря 2009 г. С. 2.

41. Ахметов Р.Р. Дом Толстого (продолжение) // Звезда Поволжья. № 45(773). 17-23 декабря 2015 г. С. 1-2.

42. Единство татарской нации : материалы науч. конф. АН РТ «Цивилизационные, этнокультурные и политические аспекты единства татарской нации» (Казань, 7-8 июня 2002 г.) / редкол.: Хасанов М.Х. и др. ; АН РТ. Казань : Фэн, 2002. 317 с. 
43. Глухов М.С. Роль партийно-советской печати в развитии татарской культуры: 1917 - начало 30-х гг. : автореф. дис. ... канд. ист. наук. Казань, 1974. 21 с.

44. Глухов М.С. Судьба гвардейцев Сеюмбеки: Неформальный подход к еще неписанным страницам истории. Казань : Ватан, 1993.287 с.

45. Глухов М.С. Начала христианства среди кряшен и современные проблемы совершенствования их религиозно-нравственного состояния // Кряшенская духовная миссия. URL: http://missiakryashen.ru/today/documents/conference-2000/glukhov/ (дата обращения: 26.10.2016).

46. Максимова В. Аркаим (на тат. языке). 28.08.2009 // Сетевой этнокультурный проект кряшенского народа «Кряшен.Ru». URL: http://www.kryashen.ru/rus.php?nrus=article_text\&id=433 (дата обращения: 26.10.2016).

47. Кореняко В.А., Кузьминых С.В. Наука и паранаука в современной отечественной археологии (по следам обсуждения «проблемы Аркаима») // Российская археология. 2007. № 2. С. 173-191.

48. Петров Ф.Н. Поселение Аркаим в научной и научно-популярной литературе // Российская археология. 2015. № 2. С. $167-176$.

49. Шишкин Ю. Аркаим - земля святая, денежная // Личный сайт академика PAH B.A. Tишкова. URL: http://valerytishkov.ru/ cntnt/nauchnaya_horoshie_t1/yushishkin.html (дата обращения: 1.09.2016).

50. Шнирельман В.А. Аркаим: археология, эзотерический туризм и национальная идея // Антропологический форум. 2011. № 14 . С. 133167.

51. Ирина Алексеевна Гатауллина (интервью газете «Семерочка». № 82. 2011 г.) // КАИ - Казанский национальный исследовательский технический университет им. А.Н. Туполева; кафедра истории и связей с общественностью. URL: http:/history.kai.ru/group/gataullina/ (дата обращения: 1.09.2016).

52. Апайчева И.А. Деятельность партийных организаций средневолжских автономий по развитию экономического сотрудничества (20-е 30-е гг.) : дис. ... канд. ист. наук. Казань, 1990. 257 л.

53. Гатауллина И.А. Среднее Поволжье в годы Новой экономической политики: социально-экономические процессы и повседневность: (на материалах Республики Татарстан, Ульяновской, Самарской, Саратовской областей) : дис. ... д-ра ист. наук. Казань, 2009.565 л.

54. Гатауллина-Апайчева И.А. Среднее Поволжье в годы новой экономической политики: социально-экономические процессы и повседневность. Казань : Изд-во Казан. ун-та, 2007. 430 с.

55. Гатауллина И.А. Современный кризис и проблема межкультурной коммуникации // Ислам и христианство в диалоге культур на рубеже тысячелетий : материалы междунар. науч.-практ. конф. 16-17 ноября 2000 г. Казань : Арт-кафе, 2001. С. 27-29.

56. Сэджвик М. Наперекор современному миру: Традиционализм и тайная интеллектуальная история XX века / пер. с англ. М. Маршака (15 главы) и А. Лазарева ; науч. ред. Б. Фаликова. М. : Новое литературное обозрение, 2014. 536 с.

57. Антоненко С. Идеология традиционализма в России // Интернет-журнал «Новая политика». URL: http://novopol.ru/ideologiyatraditsionalizma-v-rossii-text78.html (дата обращения: 1.09.2016).

58. Гатауллина И.А. Протоистория славян как проблема самоидентификации российского общества // История, языки и культуры славянских народов: от истоков к грядущему : материалы II Междунар. науч.-практ. конф. 25-26 ноября 2013 г. Прага: Vědeckovydavatelské centrum «Sociosféra-CZ», 2013. C. 6-12.

59. Абашева М.П., Криницына О.П. Проблематика национальной идентичности в славянском фэнтези // Вестник Томского государственного университета. 2010. № 332. С. 7-10.

60. Шнирельман В.А. «Светлые арийцы» и «посланцы темных сил»: заметки об особенностях современной антисемитской и расистской пропаганды // Библиотека «m.litread.net». URL: http://m.litread.me/read/443040/400000-401000?page=12 (дата обращения: 1.09.2016).

61. Шнирельман В.А. «Порог толерантности»: Идеология и практика нового расизма. М. : Новое литературное обозрение, 2011. Т. II. 856 с.

62. О русском неоязычестве. URL: http://www.dvpt.ru/?page=analytics019 (дата обращения: 1.09.2016).

63. В Королёве суд признал экстремистскими журналы и газеты. 24.10.2012 // Информационно-аналитический центр «Сова». URL: http://www.sova-center.ru/racism-xenophobia/news/counteraction/2010/12/d20618/ (дата обращения: 1.09.2016).

64. Овчинников A.B. Арийское дело профессора Гатауллиной (часть 1). 19.11.2015 // Агентство политических новостей. URL: http://www.apn.ru/publications/article34350.htm; http://rusfed24.ru/2015/11/19/ariyskoe-delo-professora-gataullinoy-chast-i// (дата обращения: 1.09.2016).

65. Овчинников А.В. Арийское дело профессора Гатауллиной (часть 2). 12.12.2015 // Агентство политических новостей; Русский федералист. URL: http://www.apn.ru/publications/article34441.htm (дата обращения: 1.09.2016).

66. Ионов И.Н. Цивилизационное сознание и историческое знание: проблемы взаимодействия / отв. ред. Л.П. Репина ; Ин-т всеобщ. истории РАН. М. : Наука, 2007. С. 252-257 («Расистская версия теории цивилизаций. А. Гобино»).

67. Шнирельман В.А. «Цепной пес расы»: диванная расология как защитница «белого человека». $3.10 .2007 / /$ Информационноаналитический центр «Сова». URL: http:/www.sova-center.ru/racism-xenophobia/publications/2007/10/d11692/ (дата обращения: 1.09.2016).

68. Ларюэль М. Александр Дугин, идеологический посредник // Цена ненависти. Национализм в России и противодействие расистским преступлениям : сб. ст. / сост.: А. Верховский. М. : Сова, 2005. С. 226-253.

69. Гриффин Р. Фашизм // ПОЛИС. 2012. № 3. С. 141-150.

70. Асеев О.В. Язычество в современной России: социальный и этнополитический аспекты : дис. ... канд. филос. наук. М., 1999. 123 с.

71. Гайдуков А.В. Идеология и практика славянского неоязычества : дис. ... канд. филос. наук. СПб., 2000.164 с.

72. Кавыкин О.И. Родноверы. Самоидентификация неоязычников в современной России. М. : Институт Африки РАН, 2007.232 с.

73. Пушная М.Л. Методы исследования региональных субкультур на примере неоязычества // Вестник Томского государственного университета. 2007. № 305. С. 59-61.

74. Гиперборейский скандал 2015 в Татарстане // Интернет-портал «Все о Гипербореe». URL: http://www.yperboreia.org/arc.asp (дата обращения: 1.09.2016).

75. Гатауллина И.А. Гиперборейский миф: проблема «исторического истока», его коннотации и интерпретации в сфере современной науки // История, память, идентичность: теоретические основания и исследовательские практики : материалы междунар. науч. конф. / под ред. О.В. Воробьевой, О.Б. Леонтьевой, С.И. Маловичко, М.Ф. Румянцевой. М. : Аквилон, 2016. С. $93-96$.

76. Видаль-Наке П. Атлантида: краткая история платоновского мифа / пер. с фр., подстроч. примеч. А. Лазарева ; ст. Ю. Литвиненко ; послесл. М. Маяцкого ; Нац. исслед. ун-т «Высшая школа экономики». М. : Изд. дом Высшей школы экономики, 2012.208 с.

77. Литвиненко Ю.Н. «Русская атлантида». К истории одного платоновского мифа // Видаль-Наке. П. Атлантида: краткая история платоновского мифа. М. : Изд. дом Высшей школы экономики, 2012. С. 172-204.

78. Шнирельман В.А. Гиперборея - между политикой, эзотерикой и искусством // Культурологические записки. 2012. Вып. 13. С. $285-322$.

79. Розенберг А. Миф ХХ в. Оценка духовно-интеллектуальной борьбы фигур нашего времени. Таллин : Shildex, 1998. 527 с.

80. Зайнуллина Г. Из города К. в город В... // Звезда Поволжья. № 12 (116). 28 марта - 3 апреля 2002. С. 4.

81. Зайнуллина Г. Татарстан - сфинкс? // Звезда Поволжья. № 13 (117). 4-10 апреля 2002 г. С. 4.

82. Зайнуллина Г. Вектор до конца // Звезда Поволжья. № 17 (121). 8-15 мая 202 г. С. 4.

83. Зайнуллина Г. Стыд и страх // Звезда Поволжья. № 25 (129). 11-17 июня 2002 г. С. 4.

84. Генетический портрет: как дивный призрак прошлых лет... (Интервью О.А. Кравцовой Г. Зайнуллиной) // Идель. 2007. № 4. С. 60-64.

85. Мамаева Т. Константин Васильев и Казань: ребрендинг территории. 26.06.2013 // БИЗНEC Online. URL: https://www.businessgazeta.ru/article/82671 (дата обращения: 1.09.2016). 
86. Жарчинская К.А. Арийская идея и гиперборейский миф в современной отечественной культуре. Опыт исследования исторической памяти посетителей музея славянской мифологии в Томске // История мировых цивилизаций: этнонациональные проблемы и пути их решения : материалы межрегион. науч.-практ. конф. с междунар. участием. Красноярск, 27 ноября 2009 г. / отв. ред. Д.В. Григорьев ; Краснояр. гос. пед. ун-т им. В.П. Астафьева. Красноярск, 2009. С. 224-237.

87. «Откуда у парня “испанская” грусть» (отзыв от 16.02.2016) // Музей Константина Bacильева. URL: https://www.tripadvisor.ru/Attraction_Review-g298520-d5521272-Reviews-or30-Konstantin_Vasilyev_s_Museum-Kazan_Republic_of_Tatarstan_Volga_District.html\#REVIEWS (дата обращения: 1.09.2016).

88. «Теперь в центре города» (отзыв от 11.11.2015) // Музей Константина Васильева. URL: https://www.tripadvisor.ru/Attraction_Reviewg298520-d5521272-Reviews-or40-Konstantin_Vasilyev_s_Museum-Kazan_Republic_of_Tatarstan_Volga_District.html\#REVIEWS (дата обращения: 1.09.2016).

89. «Это Русь» (отзыв от 11.07.2015) // Музей Константина Васильева. URL: https://www.tripadvisor.ru/Attraction Review-g298520-d5521272Reviews-or50-Konstantin_Vasilyev_s_Museum-Kazan_Republic_of_Tatarstan_Volga_District.html\#REVIEWS (дата обращения: 1.09.2016).

90. Овчинников А.В. Классический университет в современной России: «эгоистичные интеллектуалы и коллективистские идеологии...» // Классический университет: история и современность : материалы Всерос. с междунар. участием науч.-практ. конф., посв. 85-летию Удмуртского государственного университета; Ижевск, 3-4 февраля 2016 г. / отв. ред. и сост. В.В. Пузанов, Д.В. Репников. Ижевск : Удмурт. ун-т, 2016. С. 98-108.

Статья представлена научной редакцией «История» 18 декабря 2016 г.

\section{THE ARYAN MYTH IN THE NATIONALISMS OF MODERN TATARSTAN}

Vestnik Tomskogo gosudarstvennogo universiteta - Tomsk State University Journal, 2017, 415, 86-101.

DOI: $10.17223 / 15617793 / 415 / 12$

Aleksandr V. Ovchinnikov, Institute for Social and Human Knowledge (Kazan, Russian Federation). E-mail: ovchinnikov8_831@mail.ru

Keywords: Aryan myth; Bulgars; Tatars; Kryashens; nationalism; Hyperborea; neo-paganism.

The features of the functioning of the Aryan myth in the nationalisms of the Republic of Tatarstan, the subject of Russian Federation, are analyzed. The spread of this myth in the post-Soviet space is ascertained. According to the author, this problem is insufficiently studied on the materials of Tatarstan. In solving the research problem, an appeal to the Aryan myth by representatives of the Bulgarian, Tatar, Kryashen and Russian nationalisms has been identified. As part of "Bulgarism" the Aryan myth is used by M. Z. Zakiev, F.G.-Kh. Nurutdinov and others to overcome the autochthonism of the Volga Bulgars (one of the ancestors of the Kazan Tatars) and to search for prestigious ancestors and large government entities of Eurasia in the Antiquity and the Middle Ages. The author hypothesized that the "Bulgarists" borrowed the basic elements of the myth from Russian neo-pagans nationalists and "processed" them. "Aryanism" in the Tatar nationalism can be a potential alternative or complement to the myth of the Golden Horde, but up to the present it was not widely actualized in this discourse (R.S. Khakimov, V.M. Lantsov, K.M. Ziatdinov and others). Kryashen historians and publicists (M.S. Glukhov, V.A. Maksimov) used the Aryan myth to justify the fact that the Kryashens was an ancient independent people with a non-tatar ethnogenesis. The Russian version of the Aryan myth in research works, journalism and museum exhibitions of Tatarstan is unexpectedly broadly presented. The academic apologist of the Aryan myth and Hyperborea is Doctor of Historical Sciences, Professor Irina A. Gataullina. Arguing in the framework of traditionalism, the former communist ideologist retells the myths of contemporary Russian neo-pagans in her articles, and reproduces them in the textbook History (Kazan, 2014) intended for students. The textbook also describes ancient aircrafts, on which the Atlanteans and the Hyperboreans allegedly made intercontinental flights; views of racists J.A. Gobineau, G. Wirth, R. Guenon and othes; polycentricity close to polygenism - the idea of human races as different biological species, Slavs as "defenders of Troy", etc. In Tatarstan, the Aryan myth is also promoted in articles and interviews of the journalist G. Zaynullina. In the author's opinion, a wide popularization of the artist K. Vasiliev, whose museum was opened in the most lively and attractive for a tourists street in the center of Kazan, can contribute to a more massive expansion of the Aryan myth. The author made a conclusion about the use of the Aryan myth as a tool in the nationalisms of modern Tatarstan. It is interesting for amateur and professional historians. The latter defended their theses (often in the Soviet period) on the problems of the history of the 20th century, and appealed to ancient times, including the Aryan myth in the 1990s and the 2000s. The danger of actualization of the Aryan myth from the referred sources in Russian political discourse is stated.

\section{REFERENCES}

1. Nizamitdinzoda, Kh. (2006) God so svastikoy? 2006 god v Tadzhikistane ob"yavlen Godom ariyskoy kul'tury [Year with a swastika? Tajikistan declared 2006 the Year of Aryan culture]. TsentAZIYa. 14 February [Online] Available from:
[ http://www.centrasia.ru/newsA.php?st=1139908440. (Accessed: 1 September 2016).

2. STAN RADAR. (2016) Povelitel' ariytsev. Chem obernulsya kul't lichnosti v Tadzhikistane [Lord of Aryans. What the cult of personality in Tajikistan came to be]. STAN RADAR. 5 May. [Online] Available from: http://www.stanradar.com/ news/full/20679-povelitel-arijtsev-chemobernulsja-kult-lichnosti-v-tadzhikistane.html. (Accessed: 1 September 2016).

3. Shnirel'man, V.A. (2015) Ariyskiy mif v sovremennom mire [The Aryan myth in the modern world]. Vols 1-2. Moscow: Novoe literaturnoe obozrenie.

4. Zharchinskaya, K.A. (2015) Slavyano-ariyskiy mif v istoricheskom soznanii rossiyskikh traditsionalistov [Slavic-Aryan myth in the historical consciousness of Russian traditionalists]. History Cand. Diss. Tomsk.

5. Sakharov, A.N. (ed.) (2016) Istoriya Rossii s drevneyshikh vremen do nashikh dney [History of Russia from ancient times to the present day]. Moscow: AST.

6. Yur'ev, A.I. (2015) Istoriya Otechestvennoy kul'tury [History of Russian Culture]. Moscow: Russkoe pole.

7. Sabirova, D.K. (ed.) (2014) Istoriya [History]. Moscow: Knorus.

8. Fattakhov, F.Sh. (2013) Prototyurki: geograficheskie predstavleniya, bogi i yazyk [Proto-Turks: geographic representation, gods and language]. Kazan: Kazan State University.

9. Khayrullin, M.B. (2013) Puti resheniya nazrevshikh problem [Ways of solving the urgent problems]. In: Fattakhov, F.Sh. Prototyurki: geograficheskie predstavleniya, bogi i yazyk [Proto-Turks: geographic representation, gods and language]. Kazan: Kazan State University.

10. Zakiev, M.Z. (2003) Proiskhozhdenie tyurkov i tatar [The origin of the Turks and the Tatars]. Moscow: INSAN. 
11. Shnirel'man, V.A. (1998) Ot konfessional'nogo k etnicheskomu: bulgarskaya ideya v natsional'nom samosoznanii kazanskikh tatar v XX v. [From the confessional to the ethnic: Bulgar idea in the national consciousness of the Kazan Tatars in the 20th century]. Vestnik Evrazii. 1-2. pp. $137-159$.

12. Gabdurakhmanov, Kh.G. \& Sibgatullin, R.G. (1993) Zayavlenie Kazanskogo Medzhlisa bulgarskoy obshchiny (Kazan', 20 avgusta 1992 g.) [Statement of Kazan Majlis of the Bulgarian community (Kazan, August 20, 1992)]. In: Nurutdinov, F. Bulgarskiy vopros [Bulgarian issue]. Orenburg: Redaktsiya Vestnika "Bulgariya".

13. Nurutdinov, F.G-Kh. (2000) Spasite bulgar ot diskriminatsii (I.o. Prezidenta RF g-nu V.V. Putinu) [Save the Bulgars from discrimination (to Acting President of the Russian Federation Mr. Putin)]. Zvezda Povolzh'ya. 8(11). 2-6 March. pp. 2.

14. Zvezda Povolzh'ya. (2002) Otkrytoe pis'mo [Open letter]. Zvezda Povolzh'ya. 9 (113). 7-13 March. pp. 3.

15. Zakiev, M.Z. (2008) Istoriya tatarskogo naroda (Etnicheskie korni, formirovanie i razvitie) [The history of the Tatar people (ethnic origins, formation and development)]. Moscow: INSAN.

16. Fattakh, N. (1999) Yazyk bogov i faraonov [Language of gods and pharaohs]. Kazan: Tat. knizh. izd-vo.

17. Fattakh, N. (2008) Drevnie yazyki mira v sopostavlenii s tatarskim (istoriko-lingvisticheskoe issledovanie) [Ancient languages of the world in relation to Tatar (historical and linguistic research)]. Kazan: Idel'-Press.

18. Shamiloglu, Yu. (2007) [“Djagfar History”. How the Bulgarian self-consciousness was invented]. Fal'sifikatsiya istoricheskikh istochnikov $i$ natsional'nye istorii [Falsification of historical sources and national histories]. Proceedings of the Round Table. 17 September 2007. Moscow: Institute of Oriental Studies, RAS. pp. 35-39. (In Russian).

19. Nurutdinov, F.G.-Kh. (1993) Bulgary i mirovaya tsivilizatsiya [The Bulgars and world civilization]. In: Bakhshi, I. Dzhagfar Tarikhi (Istoriya Dzhagfara) [History of Djagfar]. Vol. 1. Orenburg: KOPF "Orenburg-press-kontakt"; Redaktsiya vestnika "Bulgariya”.

20. Skurlatova, O. (1979) Zagadki "Velesovoy knigi” [Riddles of the Veles Book]. Tekhnika molodezhi. 12. pp. 55-59.

21. Shcherbakov, V. (1987) Tropoy Troyanovoy [Along the Troyan Trail]. In: Smirnov, A. (ed.) Dorogami tysyacheletiy [Roads of millennia]. Moscow: Molodaya gvardiya.

22. Skurlatov, V.I. (1977) "Sled svetonosnykh" ["Light of the luminous"]. In: Sukhanov, V. (ed.) Tayny vekov [Mysteries of centuries]. Vol. 1. Moscow: Molodaya gvardiya.

23. Shnirel'man, V.A. (2012) Russkoe rodnoverie: neoyazychestvo i natsionalizm v sovremennoy Rossii [Russian Rodnoverye: nationalism and neopaganism in modern Russia]. Dialog Series. Moscow: Izd-vo BBI.

24. Skurlatov, V.I. (1987) Etnicheskiy vulkan [Ethnic volcano]. In: Smirnov, A. (ed.) Dorogami tysyacheletiy [Roads of millennia]. Vol. 1. Moscow: Molodaya gvardiya.

25. Shcherbakov, V.I. (1990) Vse ob Atlantide [All about Atlantis]. Moscow: Obshchestvo po izucheniyu tayn i zagadok Zemli.

26. Shcherbakov, V.I. (1991) Asgard-gorod bogov [Asgard - the city of the gods]. Moscow: Molodaya gvardiya.

27. Nurutdinov, F.G.-Kh. (1995) Rodinovedenie [Homeland studies]. Kazan: Tat. gazet.-zhurnal. izd-vo.

28. Nurutdinov, F.G.-Kh. (1998) My - bulgary [We are the Bulgars]. Duel'. 27 January. 2(49). [Online] Available from: http://www.duel.ru/199802/?2_4_1. (Accessed: 15 June 2016).

29. Nurutdinov, F.G.-Kh. (2010) Bolgar tarikhi [History of the Bulgars]. Kazan: RITs.

30. Miftakhov, Z.Z. (1968) Evolyutsiya sotsialistov-revolyutsionerov i taktika bol'shevikov po otnosheniyu $k$ eserovskoy partii v period pervoy russkoy revolyutsii [Evolution of the Socialist-Revolutionaries and the Bolshevik tactics in relation to the Social Revolutionary Party during the first Russian revolution]. History Cand. Diss. Kazan.

31. Miftakhov, Z.Z. \& Mulyukov, M.A. (1980) Bor'ba kommunistov Tatarii za ukreplenie diktatury proletariata v pervye gody sovetskoy vlasti: (Iz opyta raboty kommunistov $v$ sisteme sudebno-sledstvennykh uchrezhdeniy) [Fight of Tatarstan communists for the strengthening of the dictatorship of the proletariat in the first years of Soviet power: (From experience of communists' work in law enforcement agencies)]. Kazan: Kazan State University.

32. Miftakhov, Z.Z. (1998) Kurs lektsiy po istorii tatarskogo naroda [A course of lectures on the history of the Tatar people]. Kazan: Kazan State Pedagogical University.

33. Miftakhov, Z.Z. (2002) Kurs lektsiy po istorii tatarskogo naroda (1225-1552 gg.) [A course of lectures on the history of the Tatar people (12251552)]. Kazan: Kazan State Pedagogical University.

34. VKontakte. (n.d.) Bulgary-ARII. A VK Group. [Online] Available from: https://vk.com/topic-41300658_27241362. (Accessed: 15 August 2016).

35. Bochkarev, V. (2002) Volgo-Ural'skiy region v epokhu bronzy [Volga-Ural region in the Bronze Age]. In: Usmanov, M. \& Khakimov, R. (eds) Istoriya tatar [History of the Tatars]. Vol. I. Kazan: Rukhiyat.

36. Klyashtornyy, S.G. (2002) Strana ariev [Land of the Aryans]. In: Usmanov, M. \& Khakimov, R. (eds) Istoriya tatar [History of the Tatars]. Vol. I. Kazan: Rukhiyat.

37. Usmanov, M. \& Khakimov, R. (eds) (2002) Istoriya tatar [History of the Tatars]. Vol. I. Kazan: Rukhiyat.

38. Khakimov, R.S. (2002) Istoriya tatar: vzglyad iz XXI v. [The history of the Tatars: the view from the 21 st century]. In: Usmanov, M. \& Khakimov, R. (eds) Istoriya tatar [History of the Tatars]. Vol. I. Kazan: Rukhiyat.

39. Lantsov, V.M. \& Ziyatdinov, K.M. (2006) Ocherk o razvitii tsivilizatsii slavyan, kazanskikh tatar $i$ drugikh ariytsev [Essay on the development of civilization of the Slavs, the Kazan Tatars and other Aryans]. Kazan: Novoe znanie.

40. Akhmetov, R.R. (2009) Ot Atilly do prezidenta [From Attila to President]. Zvezda Povolzh'ya. 45. 3-9 December. pp. 2.

41. Akhmetov, R.R. (2015) Dom Tolstogo (prodolzhenie) [Tolstoy House (continued)]. Zvezda Povolzh'ya. 45(773). 17-23 December. pp. 1-2.

42. Khasanov, M.Kh. Et al. (eds) (2002) Edinstvo tatarskoy natsii [The unity of the Tatar nation]. Proceedings of the conference of the RT AST. Kazan. 7-8 June 2002. Kazan: Fen.

43. Glukhov, M.S. (1974) Rol' partiyno-sovetskoy pechativ razvitii tatarskoy kul'tury: 1917 - nachalo 30-kh gg. [The role of the party and the Soviet press in the development of Tatar culture: 1917 - the beginning of 1930s]. Abstract of History Cand. Diss. Kazan.

44. Glukhov, M.S. (1993) Sud'ba gvardeytsev Seyumbeki: Neformal'nyy podkhod $k$ eshche nepisannym stranitsam istorii [The fate of Seyumbeki guards: The informal approach to still unwritten pages of history]. Kazan: Vatan.

45. Glukhov, M.S. (2000) Nachala khristianstva sredi kryashen i sovremennye problemy sovershenstvovaniva ikh religiozno-nravstvennogo sostoyaniya [Beginnings of Christianity among the Kryashens and modern problems of perfection of their religious and moral state]. [Online] Available from: http://missiakryashen.ru/today/documents/conference-2000/glukhov/. (Accessed: 26 October 2016).

46. Maksimova, V. (2008) Arkaim. Kryashen.Ru. 28 August. [Online] Available from: http://www.kryashen.ru/rus.php?nrus=article_text\&id=433. (Accessed: 26 October 2016). (In Tatar).

47. Korenyako, V.A. \& Kuz'minykh, S.V. (2007) Nauka i paranauka v sovremennoy otechestvennoy arkheologii (po sledam obsuzhdeniya "problemy Arkaima") [Science and parascience in modern domestic archeology (on the discussion "Arkaim problems")]. Rossiyskaya arkheologiyaRussian Archeology. 2. pp. 173-191.

48. Petrov, F.N. (2015) Settlement Arkaim in scientific and popular literature. Rossiyskaya arkheologiya - Russian Archeology. 2. pp. 167-176. (In Russian).

49. Shishkin, Yu. (n.d.) Arkaim - zemlya svyataya, denezhnaya [Arkaim - a holy, rich land]. [Online] Available from: http://valerytishkov.ru/ cntnt/nauchnaya_horoshie_t1/yushishkin.html. (Accessed: 1 September 2016).

50. Shnirel'man, V.A. (2011) Arkaim: arkheologiya, ezotericheskiy turizm i natsional'naya ideya [Arkaim: archeology, esoteric tourism and national idea]. Antropologicheskiy forum. 14. pp. 133-167. 
51. Gataullina, I.A. (2011) Interview to Semerochka newspaper. 82. [Online] Available from: http://history.kai.ru/group/gataullina/. (Accessed: 1 September 2016). (In Russian).

52. Apaycheva, I.A. (1990) Deyatel'nost' partiynykh organizatsiy srednevolzhskikh avtonomiy po razvitiyu ekonomicheskogo sotrudnichestva (20-e 30-e gg.) [Activity of the party organizations of the Middle Volga autonomies for the development of economic cooperation ('20s-30s)]. History Cand. Diss. Kazan.

53. Gataullina, I.A. (2009) Srednee Povolzh'e v gody Novoy ekonomicheskoy politiki: sotsial'no-ekonomicheskie protsessy i povsednevnost': (na materialakh Respubliki Tatarstan, Ul'yanovskoy, Samarskoy, Saratovskoy oblastey) [The Middle Volga region during the New Economic Policy: the socio-economic processes and everyday life (on the materials of the Republic of Tatarstan, Ulyanovsk, Samara, Saratov Oblasts)]. History Dr. Diss. Kazan.

54. Gataullina-Apaycheva, I.A. (2007) Srednee Povolzh'e v gody novoy ekonomicheskoy politiki: sotsial'no-ekonomicheskie protsessy i povsednevnost' [The Middle Volga region during the New Economic Policy: the socio-economic processes and everyday life]. Kazan: Kazan State University.

55. Gataullina, I.A. (2001) [The current crisis and the problem of cross-cultural communication]. Islam i khristianstvo v dialoge kul'tur na rubezhe tysyacheletiy [Islam and Christianity in the dialogue of cultures at the turn of the millennium]. Proceedings of the international conference. 1617 November 2000. Kazan: Art-kafe. pp. 27-29. (In Russian).

56. Sedgwick, M. (2014) Naperekor sovremennomu miru: Traditsionalizm i taynaya intellektual'naya istoriya XX veka [Contrary to the modern world: Traditionalism and the Secret Intellectual History of the twentieth century]. Translated from English by M. Marshak and A. Lazarev. Moscow: Novoe literaturnoe obozrenie.

57. Antonenko, S. (2004) Ideologiya traditsionalizma v Rossii [Ideology of traditionalism in Russia]. Novaya politika. [Online] Available from: http://novopol.ru/ideologiya-traditsionalizma-v-rossii-text78.html. (Accessed: 1 September 2016).

58. Gataullina, I.A. (2013) [Protohistory of the Slavs as a problem of self-identification of the Russian society]. Istoriya, yazyki i kul'tury slavyanskikh narodov: ot istokov $k$ gryadushchemu [History, languages and culture of the Slavic peoples: from the origins to the coming]. Proceedings of the II international. Conference. 25-26 November 2013. Prague: Vědeckovydavatelské centrum “Sociosféra-CZ”. pp. 6-12. (In Russian).

59. Abasheva, M.P. \& Krinitsyna, O.P. (2010) The problem of national identity in Slavonic fantasy. Vestnik Tomskogo gosudarstvennogo universiteta - Tomsk State University Journal. 332. pp. 7-10. (In Russian).

60. Shnirel'man, V.A. (n.d.) "Svetlye ariytsy" $i$ "poslantsy temnykh sil”: zametki ob osobennostyakh sovremennoy antisemitskoy i rasistskoy propagandy ["Light Aryans" and "messengers of the dark forces": notes about the features of the modern anti-Semitic and racist propaganda]. [Online] Available from: http://m.litread.me/read/443040/400000-401000?page=12. (Accessed: 1 September 2016).

61. Shnirel'man, V.A. (2011) "Porog tolerantnosti": Ideologiya i praktika novogo rasizma ["Threshold of tolerance": ideology and practice of the new racism]. Vol. 2. Moscow: Novoe literaturnoe obozrenie.

62. Dvpt.ru. (n.d.) O russkom neoyazychestve [Russian neo-paganism]. [Online] Available from: http://www.dvpt.ru/?page=analytics019. (Accessed: 1 September 2016).

63. Sova. (2012) V Koroleve sud priznal ekstremistskimi zhurnaly i gazety [Korolev court found magazines and newspapers extremist]. Sova Information-Analytical Center. 24 October. [Online] Available from: http://www.sova-center.ru/racism-xenophobia/ news/counteraction/2010/12/d20618/. (Accessed: 1 September 2016).

64. Ovchinnikov, A.V. (2015) Ariyskoe delo professora Gataullinoy (chast' 1) [The Aryan case of Professor Gataullina (Part 1)]. Agentstvo politicheskikh novostey. 19 November. [Online] Available from: http://www.apn.ru/publications/article34350.htm; http://rusfed24.ru/ 2015/11/19/ariyskoe-delo-professora-gataullinoy-chast-i/. (Accessed: 1 September 2016).

65. Ovchinnikov, A.V. (2015) Ariyskoe delo professora Gataullinoy (chast' 2) [The Aryan case of Professor Gataullina (Part 2)]. Agentstvo politicheskikh novostey.; Russkiy federalist. 12 December. [Online] Available from: http://www.apn.ru/publications/article34441.htm. (Accessed: 1 September 2016).

66. Ionov, I.N. (2007) Tsivilizatsionnoe soznanie $i$ istoricheskoe znanie: problemy vzaimodeystviya [Civilizational consciousness and historical knowledge: problems of interaction]. Moscow: Nauka.

67. Shnirel'man, V.A. (2007) "Tsepnoy pes rasy": divannaya rasologiya kak zashchitnitsa "belogo cheloveka" [The "chain dog of the race" sofa raceology as the defender of the "white man"]. Sova Information-Analytical Center. 3 October. [Online] Available from: http://www.sovacenter.ru/racism-xenophobia/publications/2007/10/d11692/. (Accessed: 1 September 2016).

68. Laruelle, M. (2005) Aleksandr Dugin, ideologicheskiy posrednik [Alexander Dugin, an ideological mediator]. In: Verkhovskiy, A. Tsena nenavisti. Natsionalizm v Rossii i protivodeystvie rasistskim prestupleniyam [Price of hatred. Nationalism in Russia and combating racist crimes]. Moscow: Sova.

69. Griffin, R. (2012) Fashizm [Fascism]. POLIS. 3. pp. 141-150.

70. Aseev, O.V. (1999) Yazychestvo v sovremennoy Rossii: sotsial'nyy $i$ etnopoliticheskiy aspekty [Paganism in modern Russia: social and ethnopolitical aspects]. Philosophy Cand. Diss. Moscow.

71. Gaydukov, A.V. (2000) Ideologiya i praktika slavyanskogo neoyazychestva [The ideology and practice of Slavic neo-paganism]. Philosophy Cand. Diss. St. Petersburg.

72. Kavykin, O.I. (2007) Rodnovery. Samoidentifikatsiya neoyazychnikov v sovremennoy Rossii [Rodnovers. Identity of neo-pagans in contemporary Russia]. Moscow: Institute for African Studies, RAS.

73. Pushnaya, M.L. (2007) Metody issledovaniya regional'nykh subkul'tur na primere neoyazychestva [Methods of research of regional subcultures by example of neo-paganism]. Vestnik Tomskogo gosudarstvennogo universiteta - Tomsk State University Journal. 305. pp. 59-61.

74. Yperboreia.org. (2015) Giperboreyskiy skandal 2015 v Tatarstane [Hyperborean scandal of 2015 in Tatarstan]. [Online] Available from: http://www.yperboreia.org/arc.asp. (Accessed: 1 September 2016).

75. Gataullina, I.A. (2016) [Hyperborean myth: the problem of "historical source", its connotations and interpretations in the field of modern science]. Istoriya, pamyat', identichnost': teoreticheskie osnovaniya i issledovatel'skie praktiki [History, memory, identity: theoretical foundations and research practice]. Proceedings of the international conference. Moscow: Akvilon. pp. 93-96. (In Russian).

76. Vidal-Naquet, P. (2012) Atlantida: kratkaya istoriya platonovskogo mifa [Atlantis: a brief history of the Platonic myth]. Translated from French by A. Lazarev. Moscow: Higher School of Economics.

77. Litvinenko, Yu.N. (2012) "Russkaya atlantida". K istorii odnogo platonovskogo mifa ["Russian Atlantis". On the history of the Platonic myth]. In: Vidal-Naquet, P. Atlantida: kratkaya istoriya platonovskogo mifa [Atlantis: a brief history of the Platonic myth]. Translated from French by A. Lazarev. Moscow: Higher School of Economics.

78. Shnirel'man, V.A. (2012) Giperboreya - mezhdu politikoy, ezoterikoy i iskusstvom [Hyperborea - between politics, spirituality and art]. Kul'turologicheskie zapiski. 13. pp. 285-322.

79. Rozenberg, A. (1998) Mif XX v. Otsenka dukhovno-intellektual'noy bor'by figur nashego vremeni [Myth of the 20th century. Evaluation of the spiritual and intellectual struggle of figures of our time]. Tallin: Shildex.

80. Zaynullina, G. (2002) Iz goroda K. v gorod V... [From city K to city V . . .]. Zvezda Povolzh'ya. 12 (116). 28 March - 3 April. pp. 4.

81. Zaynullina, G. (2002) Tatarstan - sfinks? [Is Tatarstan a Sphinx?]. Zvezda Povolzh'ya. 13 (117). 4-10 April. pp. 4.

82. Zaynullina, G. (2002) Vektor do kontsa [Vector to the end]. Zvezda Povolzh'ya. 17 (121). 8-15 May. pp. 4.

83. Zaynullina, G. (2002) Styd i strakh [Shame and fear]. Zvezda Povolzh'ya. 25 (129). 11-17 June. pp. 4. 
84. Zaynullina, G. (2007) Geneticheskiy portret: kak divnyy prizrak proshlykh let... (Interv'yu O.A. Kravtsovoy) [Genetic portrait: like a wonderful ghost of the past years ... (Interview of O.A. Kravtsova)]. Idel'. 4. pp. 60-64.

85. Mamaeva, T. (2013) Konstantin Vasil'ev i Kazan: rebrending territorii [Konstantin Vasiliev and Kazan: rebranding the territory]. BIZNES Online. 26 June. [Online] Available from: https://www.business-gazeta.ru/article/82671. (Accessed: 1 September 2016).

86. Zharchinskaya, K.A. (2009) [The Aryan idea and the Hyperborean myth in modern Russian culture. Previous studies of the historical memory of visitors to the Museum of Slavic Mythology in Tomsk]. Istoriya mirovykh tsivilizatsiy: etnonatsional'nye problemy i puti ikh resheniya [History of World Civilizations: ethno-national problems and their solutions]. Proceedings of the inter-regional conference. Krasnoyarsk. 27 November 2009. Krasnoyarsk: Krasnoyarsk State Pedagogical University. pp. 224-237. (In Russian).

87. Konstantin Vasiliev Museum. (2016) "Otkuda u parnya "ispanskaya” grust"” (otzyv ot 16.02.2016) ["Where does the guy have the Spanish "sadness" from?" (review of 16 February 2016)]. [Online] Available from: https://www.tripadvisor.ru/Attrac-tion_Review-g298520-d5521272Reviews-or30-Konstantin_Vasilyev_s_Museum-Kazan_Republic_of_Tatarstan_Volga_District.html\# REVIEWS. (Accessed: 1 September 2016).

88. Konstantin Vasiliev Museum. (2015) "Teper' v tsentre goroda" (otzyv ot 11.11.2015) ["Now in the heart of the city" (review of 11 November 2015)]. [Online] Available from: https://www.tripadvisor.ru/Attraction_Review-g298520-d5521272-Reviews-or40Konstantin_Vasilyev_s_Museum-Kazan_Republic_of_Tatarstan_Volga_District.html\#REVIEWS. (Āccessed: 1 September 2016).

89. Konstantin Vasiliev Museum. (2015) "Eto Rus", (otzyv ot 11.07.2015) ["This is Rus" (review of 11 July 2015)]. [Online] Available from: https:/www.tripadvisor.ru/Attraction_Review-g298520-d5521272-Reviews-or50-Konstantin_Vasilyev_s_Museum-

Kazan_Republic_of_Tatarstan_Volga_District.html\#REVIEWS. (Accessed: 1 September 2016).

90. Ovchinnikov, A. . . (2016) [Classical university in modern Russia: "selfish intellectuals and collectivist ideologies"]. Klassicheskiy universitet: istoriya i sovremennost' [Classical university: history and modernity]. Proceedings of the conference on the 85th anniversary of Udmurt State University. Izhevsk. 3-4 February 2016. Izhevsk: Udmurt State University. pp. 98-108. (In Russian).

Received: 18 December 2016 